The Effect of R\&D Growth on Employment and Self-Employment in Local Labour Markets

\author{
Tommaso Ciarli, Alberto Marzucchi, \\ Edgar Salgado and Maria Savona
}

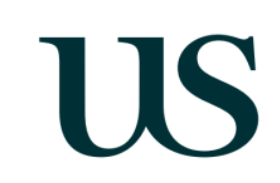




\section{SPRU Working Paper Series (ISSN 2057-6668)}

The SPRU Working Paper Series aims to accelerate the public availability of the research undertaken by SPRU-associated people, and other research that is of considerable interest within SPRU, providing access to early copies of SPRU research.

\section{Editors}

Tommaso Ciarli

Daniele Rotolo

Associate Editors
Karoline Rogge
Paul Nightingale,
Ben Martin, \&
Ohid Yaqub
Tommaso Ciarli
Joe Tidd \&
Carlos Sato
Maria Savona
Andrew Stirling
Caitriona McLeish
Editorial Assistance
Martha Bloom

\section{Contact}

T.Ciarli@sussex.ac.uk

D.Rotolo@sussex.ac.uk

\author{
Area \\ Energy \\ Science, \& Technology Policy \\ Development \\ Technology Innovation Management \\ Economics of Technological Change \\ Transitions \\ Civil Military Interface \\ K.Rogge@sussex.ac.uk \\ P.Nightingale@sussex.ac.uk \\ B.Martin@sussex.ac.uk \\ O.Yaqub@sussex.ac.uk \\ T.Ciarli@sussex.ac.uk \\ J.Tidd@sussex.ac.uk \\ C.E.Y.Sato@sussex.ac.uk \\ M.Savona@sussex.ac.uk \\ A.C.Stirling@sussex.ac.uk \\ C.A.McLeish@sussex.ac.uk
}

\section{Guidelines for authors}

Papers should be submitted to swps@sussex.ac.uk as a PDF or Word file. The first page should include: title, abstract, keywords, and authors' names and affiliations. The paper will be considered for publication by an Associate Editor, who may ask two referees to provide a light review. We aim to send referee reports within three weeks from submission. Authors may be requested to submit a revised version of the paper with a reply to the referees' comments to swps@sussex.ac.uk. The Editors make the final decision on the inclusion of the paper in the series. When submitting, the authors should indicate if the paper has already undergone peer-review (in other series, journals, or books), in which case the Editors may decide to skip the review process. Once the paper is included in the SWPS, the authors maintain the copyright.

\section{Websites}

UoS: www.sussex.ac.uk/spru/research/swps

SSRN: http://www.ssrn.com/link/SPRU-RES.html

IDEAS: ideas.repec.org/s/sru/ssewps.html

Research Gate: www.researchgate.net/journal/2057-6668_SPRU_Working_Paper_Series 


\title{
The effect of R\&D Growth on Employment and Self-Employment in Local Labour Markets*
}

\author{
Tommaso Ciarli ${ }^{\dagger}$ \\ Alberto Marzucchi ${ }^{\ddagger}$ \\ Edgar Salgado§ \\ Maria Savona
}

March 2018

\begin{abstract}
The paper investigates the effects of firms' investment in Research and Development (R\&D) on employment dynamics in the British local labour markets (Travel to Work Areas). We distinguish between local areas characterised by the initial level of routinised employment of the workforce. We implement a instrumenting strategy to address endogeneity issues in the relation between innovation and employment. Our results suggest that increases in R\&D investments mainly affect routinised areas, where the employment created is low skilled, concentrated in non-tradable sectors (like transport, construction) and services. A significant share of the jobs created is self-employment, concentrated in the 25-34 age cohort. We qualify the effect of R\&D on self-employment by looking at local firms' dynamics, which suggest that the increase in self-employment is reflected in a higher number of micro-firms. Rather, in non-routinized areas, $R \& D$ results in the expected increase in the demand of high-skilled workers and a reduced demand of low-skill employment.

Keywords: Innovation; R\&D investments; Employment; Self-employment; Local Labour Markets; Routinisation; Skills.

JEL: O33; J24; D3
\end{abstract}

\footnotetext{
*The paper is an output of the ESRC SDAI III Grant n. 179003 TEMPIS: Technical change, EMPloyment \& Inequality. A Spatial analysis of households \& plant data. We thank the editor and two anonymous referees from the SPRU Working Paper series for valuable comments. This work has also benefited from discussion and suggestions by Davide Consoli, Francesco Rentocchini, Francesco Vona and all participants at the Ingenio Dpt Seminars held in June 2017; EAPEE conference held in September 2017; GEOINNO held in February 2018. The paper is based on data accessed through the UK Secure Data Service and uses data sets which may not exactly reproduce aggregate National Statistics. The original data creators, depositors or copyright holders, the funders of the Data Collections (if different) and the UK Data Archive bear no responsibility for any analysis or interpretation in this article. All errors remain the responsibility of the authors. We are grateful to the UKDS for making the data available.

†SPRU, University of Sussex, t. ciarli@ sussex.ac.uk

¥SPRU, University of Sussex, a.marzucchi@ sussex.ac.uk

\$Corresponding author: SPRU, University of Sussex, E.Salgado-Chavez@ sussex.ac.uk

`SPRU, University of Sussex, M.Savona@ sussex.ac.uk
} 


\section{Introduction}

The effect of technical change on the rate, growth and composition of employment has long been debated, since the Luddites (Freeman et al.; 1982; Freeman and Soete; 1987) ${ }^{1}$ The recent concerns on the job-loss effect of robotisation in the US (Brynjolfsson and McAfee; 2014; Autor and Salomons; 2017) and the UK (Frey and Osborne; 2013, 2015; Graetz and Michaels; 2015) have brought technological unemployment back to the forefront of the debate in academic and policy circles (Sachs et al.; 2015; Summers; 2013).

There have been different technological waves: from the steam-powered machines of the first industrial revolution to the Information and Communication Technologies (ICTs) in the 1980s and, more recently, robots and artificial intelligence are the core of the fourth industrial revolution. With the characteristics of General Purpose Technologies (GPTs) (Bresnahan and Trajtenberg; 1995), i.e. typically with a large number and pervasiveness of applications, they differ substantially in their job-destruction and job-creation effects, and in their impact on productivity growth and employment composition in terms of skills, tasks and labour organisation.

With evidence of falling labour shares (Autor et al.; 2017a) and increased job polarisation (Goos et al.; 2014a), theories and empirics seem to face several challenges. We argue here that the understanding of the complex effects of technical change on employment depends on: (i) how technological innovation is proxied and measured; (ii) the level of analysis adopted: the effects of technology adoption on labour at the firm level might be offset at the industry level or within local labour markets and, ultimately, at the national level; (iii) whether different employment categories beyond paid employment are considered: in the case of innovation, entrepreneurial or coping self-employment might play a substantial role in job creation, destruction and recomposition.

The adoption of new technologies in production processes, aimed at increasing the stock of marketable novel applications, is the result of R\&D investments in firms. Empirical evidence on the rate of returns to $R \& D$ via productivity growth seems to suggest a virtuous dynamic between R\&D, productivity and employment (Cincera and Rheinilde; 2014; Hall et al.; 2008, 2010). However, such virtuous cycle seems broken (Gallegati et al.; 2015) for the recent UK context. From 1991 to 2011 business R\&D measured as a share of DGP (figure 1) has mostly declined, TFP followed a rather different up (1991-2001) and down (2001-2011) period (figure 2).

[Figures 1 and 2 around here]

The traditional idea that R\&D might trigger a positive effect on employment, based on the potential for compensation mechanisms via new products, productivity growth, lower prices and increased demand (Calvino and Virgillito; 2016; Piva and Vivarelli; 2017) seems to be challenged. Not only 'ideas are getting harder to find' (Bloom et al.; 2017), with the productivity elasticity of research having declined substantially over the past decades, but research investments seems to be concentrated in a few 'superstar firms' (Autor et al.;

\footnotetext{
${ }^{1}$ See also Piva and Vivarelli (2017) for a recent review.
} 
2017b), with a declining average employment elasticity of research investments in the US, ultimately leading to a fall of the aggregate labor share (Autor et al.; 2017a).

Yet, employment dynamics in the UK seem to be at its highest rate since decades (Haldane; 2017), despite the 2008 crisis (Crawford et al.; 2013; Pessoa and Van Reenen; 2014). Interestingly, Figure 3 shows the dynamics of self-employment in the UK over the past decades and suggests that self-employment has been steadily growing, and most likely compensating the fall in employment. Interestingly, this pattern seems to be immune to the business cycle, suggesting that a structural phenomenon might be at work.

[Figure 3 around here]

This employment trend disguises a substantial degree of spatial polarisation, which the theory attributes, among other things, to sectoral and geographical agglomeration of activities (Powell et al.; 2002; Echeverri-Carroll and Ayala; 2009; Meliciani and Savona; 2014) that have an effect on labour market dynamics (Korpi; 2007; Matano and Naticchioni; 2011; Berger and Frey; 2016) and types of jobs (Moretti; 2010a).

In this paper we aim to empirically disentangle the compensation mechanisms at work in local labour markets that experience increases in R\&D investments. Theoretically, we build on the model framework proposed in Autor and Dorn (2013b) and Goos et al. (2014b). We aim to contribute to the literature is threefold. First, rather than looking at the innovation performance (i.e. patents) of firms (Aghion et al.; 2015), we take into account R\&D investments, as a proxy of innovation strategy of firms. As we argue later on, these might entail trade-offs in the choice of allocating resources to alternative inputs such as labour. Second, we incorporate in the analysis the role of sectoral and spatial specificities of the UK economy, to unravel disparities behind the national figures. Third, we extend the analysis of the effects of R\&D shocks extend to self-employment.

In line with Autor and Dorn (2013b), we assume that local labour markets are characterised by homogeneous levels of routinisation of the workforce and that firms highly investing in R\&D are more likely to locate in local markets with a low degree of routinised labour force. We also assume that Travel-To-Work-Areas (TTWAs) ${ }^{2}$ with different degrees of initial routinisation will differentially invest in $R \& D$, attract superstar firms (Autor et al.; 2017a,b), and have different distribution of firm size.

We empirically test the following questions:

- What is the overall effect of firm innovative activity (R\&D investments) on the growth and composition of employment in the UK local labour markets? (Travel-To-WorkAreas (TTWA))?

- Does the effect differ between local labour markets with low and high initial share of routinised employment?

- What kind of employment (paid or self-employment) is created/destructed by R\&D?

\footnotetext{
${ }^{2} \mathrm{~A}$ detailed definition of TTWA is provided below in Section 3.
} 
We find that an increase in firm innovation activity, ceteris paribus, increases the share of high skilled workers, reshuffling the employment composition from low to high skilled. When we distinguish between areas with high and low initial levels of routinisation of the workforce, we find that in areas with a high concentration of routinised occupations, R\&D reshuffles the composition towards low skilled, increasing by two thirds the number of self-employed. The effect is particularly strong for the cohort of graduates and early careers (25-34), males and in services, transport and construction activities. When we zoom into the effects of R\&D on firm dynamics to qualify the nature of the self-employment, we find that the self-employment created is mainly 'unincorporated'. This suggests that it is hardly attributable to creative entrepreneurial ventures, but most likely to coping strategies alternative to paid employment.

These findings contribute to both the labour economics and innovation literatures by providing a policy relevant picture of the local labour markets effect of R\&D growth, in a country characterized by a unique, service-intensive sectoral structure, geographical polarization, national industrial strategy and at a crucial historical moment within the wider European labour market.

The remainder of the paper is structured as follow. Section 2 briefly reviews the relevant literature. Section 3 discusses the estimation and identification strategies, and the data employed. Section 4 discusses the results, while Section 5 summarises the main findings ${ }^{3}$.

\section{Background}

\subsection{Given wisdom and new challenges}

Old and new theories have not come yet to uncontroversial explanations of how technical progress affects labour, as emerged in recent evidences (Dachs et al. (2016)). One of the most influential theoretical frameworks, the skill-biased technical change (SBTC) hypothesis (Acemoglu and Autor (2011); Saint-Paul (2008)), predicts that if innovation increases the demand for skilled labour and skills are slow to adjust, the excess of supply of unskilled labour and the low supply of skilled labour may trigger employment polarisation.

The theory has recently incorporated evidence on mid-skill jobs growing comparatively less than high- and low-skill ones (Autor et al.; 2005; Faggio et al.; 2010). The routine-replacing technical change (RRTC) framework (Autor and Dorn; 2013b; Goos et al.; 2014b; Van Reenen; 2011) explains this recent evidence on employment polarisation with the increased automation of works commanding routinised tasks. In their seminal article, (Autor and Dorn; 2013b) develop a theoretical argument and derive empirically testable hypotheses on the effect of a more pervasive adoption of ICTs. ICTs have gone through unrelenting falling cost of capital over the last three decades, and have replaced automated, routinised tasks in the US. The authors find interesting results at the level of local labour market: 'Local labor markets that specialized in routine tasks differentially adopted information technology, reallocated low-skill labor into service occupations (employment polarization), experienced earnings growth at the tails of the distribution (wage

\footnotetext{
${ }^{3}$ All tables and figures are reported in the Appendix.
} 
polarization), and received inflows of skilled labor." (Autor and Dorn; 2013a, p.1) The main factors accounted for in this framework are the initial (task) specialisation in local labour markets, which determines the rate of adoption of technologies expected to replace specific tasks and the extent to which dismissed jobs are then re-employed in local lower-skilled occupations. The employment polarisation towards low skill (service) jobs in the US seems also attributed to the increased consumption coming from high-skill workers Mazzolari and Ragusa (2013).

Besides the polarisation effects explained by the SBTC and RRTC frameworks, the most recent evidence on the steady decline of the US labour share since the 1980's (Fleck et al.; 2011; Karabarbounis and Neiman; 2013) has led scholars to look at explanations linked to market structure dynamics resulting from technical change. For instance, Autor et al. $(2017 a, b)$ argue that the decline of the labour share of GDP is attributable to the specific firm dynamics that characterise industries with higher sales concentration: "technological change has made markets increasingly "winner take most" so that superstar firms with higher productivity increasingly capture a larger slice of the market" (Autor et al.; 2017a, p.6). However, it is argued, these leading few, superstar firms increase their market shares and profits, and yet employ a proportionally lower number of people. While the role of superstar firms, particularly those who benefit from cumulative increasing returns from $R \& D$ investments, is not new in the economics of innovation literature (see seminal contributions in Griliches (1979); Hall et al. (2008)), it remains to be explained why the employment elasticity of superstar firms' R\&D-led growth seems to have slowed down more recently. Do 'returns on ideas' (Autor et al.; 2017a) risk to saturate in the near future?

\subsection{R\&D and employment}

Labour economists tend to proxy technology with (tangible) capital investments, such as ICTs ()VanReenen2011,AutDor13,BryMca14,Michaels2014, and more recently the adoption of robots, advanced types of automation and Artificial Intelligence (Frey and Osborne; 2015; Graetz and Michaels; 2015; Autor and Salomons; 2017), or patents (Aghion et al.; 2015).

Rather, following the seminal work by Freeman et al. (1982) and Freeman and Soete (1987), economists of technical change consider innovation first and foremost as a result of investments in R\&D. R\&D allows the creation and adoption of new technologies in production processes, and of marketable novel applications, which ideally increase firms' market shares and knowledge stock. The theoretical grounding of the economics of innovation is based on the presence (and functioning) of the compensation mechanisms, originally put forward by Marx (for a review, see Calvino and Virgillito (2016) and Piva and Vivarelli (2017)). Empirical studies of the effects of innovation on employment (Hall et al. (2008); Piva and Vivarelli (2017)) mainly source evidence on R\&D from the Community Innovation Survey (CIS), which follows the OECD Frascati Manual standards ${ }^{4}$. The empirical

\footnotetext{
${ }^{4}$ In the internationally agreed standards defined by the Organisation for Economic Cooperation and Development (OECD) Frascati Manual, R\&D is defined as 'creative work undertaken on a systematic basis in order to increase the stock of knowledge, including knowledge of man, culture and society and the use of this stock of knowledge to devise new applications". The basic measure is 'intramural expenditures", that are all current and capital expenditures for R\&D performed within a statistical unit or sector of the economy
} 
operationalisation of compensation mechanisms is generally limited to the differential effect of process and product innovation on employment. The intuition is twofold: process innovation is intrinsically aimed at (labour) cost-saving and therefore is job-displacing, in the same vein that automation and digital technologies have displaced jobs more recently (Brynjolfsson and McAfee; 2012; Frey and Osborne; 2015). Product innovation might instead be job-creating, via compensation mechanisms that work through falling prices and demand increases, among others. The implicit assumption behind compensation mechanisms is that investments in R\&D are predominantly leading to product innovations, which, provided that they do not completely displace obsolete products, increase demand; rather, embodied (in capital goods) technical change is predominantly aimed at process innovations and therefore mostly have a job displacing effect. Empirical evidence on the rate of returns to R\&D to (product) innovation, via productivity growth, seems to support this intuition (Cincera and Rheinilde; 2014; Hall et al.; 2010).

However, the activation of a compensation mechanism via increases in demand following the introduction of new products is intrinsically uncertain, as performing R\&D might not automatically lead to the creation of new products. A more appropriate proxy for the intensity of product innovation is offered by patents and has been used in the literature Aghion et al. (2015). However, while most patenting firms most likely will have performed $R \& D$ at some stage, not all firms investing in R\&D are ultimately able to patent. The use of patents as a proxy for technical change in this context might therefore risk to underestimate the effect of innovation on employment. Conversely, R\&D captures innovation effort and thus the resources -including human ones- that the firm commits to innovation even before the innovation is realized. There is therefore an intrinsic trade-off in the choice of allocating resources to $\mathrm{R} \& \mathrm{D}$ and alternative inputs such as labour.

In sum, we argue here that it is the actual R\&D strategy that dictates the employment and skill needs of a firm and that the most comprehensive effect of innovation on employment might be captured by proxing innovation with R\&D investments. Yet, R\&D investments are of a composite nature and entail resources that are devoted to specific high-skill workers who performs creative tasks such as basic and applied research, while not all high skilled workers such as scientists and engineers perform R\&D (Barth Erling and Wang (2017)). The direct effects of R\&D on employment might result from an increased demand for skilled workers performing non-routinised tasks; it might also need and spur demand for complementary (routinised) tasks to be performed by lower-skill workers (Autor and Dorn (2013b); Mazzolari and Ragusa (2013)).

\subsection{Local labour markets and self-employment}

Arguably, a firm increasing its R\&D investments would recruit specific as well as complementary tasks (and indeed displace redundant and substitutive ones), depending on the initial availability of these within the local labour markets which it is located in. Hence, the initial employment structure and the availability of a pool of specific skills within a local labour market is likely to play a crucial role in the net effect of innovation on paid employment. These characteristics are likely to be very much path-dependent, i.e. subject to a limited degree/direction of radical change once they are established. This implies that 
local labour markets are likely to be subjected to slow changes and therefore firms located in a certain area are likely to adapt their investment and recruiting strategy to their location rather than vice-versa, within a time-span such as the one considered here. Accordingly, the spatial heterogeneity in the concentration of routinised and non routinised workforce at the level of local labour market is a determinant to account for when investigating the effect of R\&D on employment.

In the case of the UK, as mentioned, local labour market are identified as Travel-ToWork-Areas (TTWA). TTWAs that experience increases in R\&D investments might also attract new entrepreneurial ventures that reshape the initial employment composition towards self-employment.

The spectrum of self-employment is quite large, and includes the entrepreneurial venture attracted by new technological opportunities spurred by high investments in R\&D, but also an increase in self-employment as a 'coping' strategy resulting from paid employment dismissal (see also Manyika et al. (2016)). On the one hand of the spectrum self-employed might identify in the creative entrepreneur, attracted by new technological opportunities. On the other hand, self-employment might be the result of skills mis-matches triggered by the innovation process itself (Thomas Åstebro (2011); Vona and Consoli (2015a)) or indeed a coping strategy for people pushed out of the labour market (Thurik et al.; 2008b). This phenomenon is increasingly documented in the literature, as shown by (Katz and Krueger; 2016). Along these lines, evidence has been shown on the composite nature of self-employment, which is linked to the nature of the entrepreneurial venture, which might be relevant for the purpose of our work. For instance (Levine and Rubinstein; 2017) distinguish between incorporate and unincorporated self-employment, and show that while incorporated self-employed is usually associated to increases in non-routinised workforce, unincorporated self-employed makes use of relatively higher routinised workforce. Innovation in other words might contribute to 'smart' entrepreneurs as well as force workers into 'illicit' activities as a result of coping strategies ((Levine and Rubinstein; 2017)).

Indeed, self-employment has increased dramatically in the US (Katz and Krueger (2016)), to the point of representing the bulk of the US employment growth over the last few years, and in the UK (Figures ??). In the UK, the debate around the so called Gig Economy has shown an upward trend of self-employed in the UK (Adams et al. (2017)). Gigged workers are characterised by the delivery of tasks - mainly services - through the use of digital platforms, to the extent that the Gig Economy has also been labelled as the Platform Economy (Kenney and Zysman (2016)), and usually with unprecedented time flexibility. It has been argued that gigged workers represent a generational change with respect to previous types of self-employed Adams et al. (2017) and concern is growing around the conditions of work in the 'Gig Economy'. These include the precarisation and fragmentation of jobs relying on digital platforms (Balaran et al. (2017); Manyika et al. (2016)); the regulatory issues, such as the taxation of the self-employed ((Adams et al.; 2017)); the substantial fall in wages, as recently put forward by the Bank of England ${ }^{5}$ A novel addition of our work is in the inclusion of self-employment as an important component of the employment effect of innovation.

\footnotetext{
${ }^{5}$ See Andrew Haldane, Chief Economist, Bank of England, on Work, Wages and Monetary Policy, June 2017.
} 
To sumamrise, innovation can be disruptive in many ways or create new entrepreneurial opportunities that act as a compensation mechanism to jobs made redundant. Both job redundancies and entrepreneurial opportunities depend on the historical specialisation and path dependency in terms of sectoral and employment composition that characterise regions and local labour markets. The UK typically present a substantial degree of spatial heterogeneity, with areas specialised in mature manufacturing characterised by a high share of routinised workforce and (urban) areas dense in knowledge intensive business services that employ non-routinised workforce. As a result, it is likely that R\&D investment in Cambridge (UK) (or Palo Alto (US)) is probably not like R\&D investment in Selby (Yorkshire) (or Dalton (GA)). Similarly, being self-employed in Cambridge (UK) (or Palo Alto (US)) is probably not like the self-employment (entrepreneurial) opportunities in Selby (Yorkshire) (or Dalton (GA)). We take all this into account in empirically addressing our research questions.

\section{Data and methods}

\subsection{Data}

We combine different data sets to produce variables at the TTWA level. We use data from the population census to construct labour outcomes. The primary source for the census data is the Office of National Statistics (ONS), but we use the census aggregates elaborated by the UK Data Service ${ }^{6}$ and NOMIS ${ }^{7}$.

We include 212 TTWAs from England, Scotland and Wales that we observe in two periods, 2001 and 2011.

From the census we also retrieve information on the occupational categories that we use to define routine-intensive areas. Available data from the census, the NS-Sec classification, allow us to distinguish between seven categories: higher managerial and professional occupations, lower managerial and professional occupations, intermediate occupations, small employers and own account workers, lower supervisory and technical occupations, semi- routine occupations, and routine occupations. We calculate the share of labor accrued by routine occupations in every TTWA in 2001.

Figure 4 plots the labor share of routine occupations. By 2001, the south of Britain had the lowest routine share, while cities in the north have a larger share of routine employment. The median share across cities is 0.13 , and it is from this threshold that we identify routinised TTWAs, i.e. areas where the share of routinised workers is larger than 0.13 .

[Figure 4 around here]

Information on R\&D expenditures is retrieved from the Business Expenditure on Research and Development (BERD) survey implemented by ONS to calculate the expendit-

\footnotetext{
${ }^{6}$ We use Casweb to retrieve data for the years 1991 and 2001. https://census.ukdataservice.ac.uk/getdata/aggregate-data

${ }^{7}$ For the year 2011. https://www.nomisweb.co.uk/census/2011
} 
ure in R\&D. The survey is a sub-set of the Annual Business Survey (ABS). According to the design of BERD, every year there are around $400-500$ businesses responsible for $80 \%$ of UK business R\&D expenditures. BERD targets $93 \%$ of these businesses in its sample design. And actually it is a census of big contributors: the survey follows these firms every year. For the remaining $20 \%$ of UK business R\&D, BERD targets $90 \%$, with an important under-coverage for small businesses: 9.6\% for businesses with less than 10 employees (Ker and Greenaway; 2012). Therefore, we focus the analysis as to understand the effect of R\&D expenditure from the large R\&D contributors, without making any claim about statistical representation for the R\&D expenditure of all firms in the UK.

We calculate R\&D at the TTWA level as the average R\&D expenditure per worker within the TTWA. For each year (2001 and 2011) we use three years of data to improve precision. For year $t$, we use information of all the firms surveyed by BERD in years $t-1$, $t$ and $t+1$, and estimate the following equation using firm's turnout as weight:

$$
\ln R D_{f t i}=\alpha+\beta \ln \text { Employees }_{f t}+\theta_{i}+\tau_{t}+\varepsilon_{f t i}
$$

Where $R D_{f t i}$ is the total R\&D expenditure of firm $f$ in year $t$ and TTWA $i$. Employees $f t$ is the number of employees as reported in the IRDB, $\tau_{t}$ is a dummy variable for each year, and $\theta_{i}$ is a dummy variable for each TTWA. We recover the estimated coefficient $\hat{\theta}_{i}$ for years 2001 and 2011 that we use to calculate our measure of R\&D growth at the TTWA level: $\Delta R D_{i}=\hat{\theta}_{2011}-\hat{\theta}_{2001}$.

\subsection{Econometric strategy}

In what follows we present the empirical approach we adopt to address our research questions.

Our main objective is to estimate the impact of innovation on the changes in the labour market. Operationally, we employ a set of dependent variables that capture different dimensions of the composition of the local labour market outcomes generated by R\&D investments. These include: employment and unemployment, of high-skilled and lowskilled workers, paid labour and self-employed, and different age cohorts. For the sake of brevity, $y$ denotes our dependent variables, while our key explanatory variable, $R D$ reflects the investment in R\&D at the local level. We take the Travel to Work Area (TTWA) as our unit of analysis, $i$.

The link between R\&D and local labour market outcomes is then defined by the following equation:

$$
\Delta y_{i t}=\alpha+\beta \Delta R D_{i t}+\gamma_{c}+\varepsilon_{i t}
$$

We explore how changes in $R \& D$ are related to changes in labour outcomes. This strategy by definition rules out any unobserved fixed effect at the TTWA level. ${ }^{8} \Delta y_{i t}$ is the change from 2001 to 2011 of labour outcome $y$ in TTWA, while $\Delta R D_{i t}$ is the change in

\footnotetext{
${ }^{8}$ Taking the first differences allows us to eliminate time invariant TTWA-level unobserved characteristics, including -among others- the TTWA idiosyncratic exposure to the 2007-08 global financial crisis.
} 
the average firms' research and development expenditure at the TTWA level. $\gamma_{c}$ captures country-specific (for England, Scotland and Wales) trends and $\varepsilon_{i t}$ is the statistical disturbance.

We are not only interested in the aggregate effect of R\&D over labour outcomes but also on its heterogeneity arising from the initial degree of routinisation of the labour market. Autor et al. (2003) and Autor and Dorn (2013a), among others, have highlighted the role played by routine occupations in the explanation of employment polarisation. This becomes more important if we consider the investment in innovation activities as (R\&D) as interrelated with the degree of routinisation of production activities and hence of jobs. We explore this heterogeneity by interacting $\Delta R D_{i t}$ with $\phi$, which captures whether the $i-t h$ TTWA is characterised by an above-median share of routinised employment in $2001^{9}$ :

$$
\Delta y_{i t}=\alpha+\beta_{1} \Delta R D_{i t}+\beta_{2} \phi \times \Delta R D_{i t}+\gamma_{c}+\varepsilon_{i t}
$$

Estimating equations 2 and 3 with OLS would yield biased coefficients for R\&D ${ }^{10}$ due to reverse causality, unobserved heterogeneity and measurement error. On the first, it is possible to argue that employment growth drove the development of R\&D activities within the city. On the second, and perhaps more important some unboserved factors not captured in our estimation boosted both employment growth and R\&D development within the city. For instance, the opening of a research centre would create employment opportunities and also be the source of R\&D developments. Finally, measurement error in the reporting of R\&D is likely.

We address these issues using an Instrumental Variables (IV) approach that exploits the initial compositions of output across industries interacted with the nationwide change in industry R\&D (excluding the TTWA). We use the initial output share of industries ${ }^{11}$ within each TTWA to predict the change in R\&D at the TTWA. In this way we isolate the change in R\&D across TTWAs due to changes in nation-wide (excluding the TTWA) dynamics in $R \& D$ and not to particular shocks to the TTWA that would be otherwise correlated with the TTWA labour outcome.The source of identification comes from differing base year industry compositions across TTWA. As Baum-Snow and Ferreira (2015) state, "[t]he validity of this instruments relies on the assertion that neither industry composition nor unobserved variables correlated with it directly predict the outcome of interest conditional on controls". It is worth mentioning at this point that the exclusion of the corresponding TTWA in the estimation of the nationwide change in R\&D at the industry level helps us to account for local unobservables that may drive both employment variables and local R\&D. Therefore, we use only aggregate variation at the industry level, which is also external to the relevant

\footnotetext{
${ }^{9}$ Table 1 lists the top and bottom TTWAs according to their degree of initial routinised employment as in 2001. The average and median share of routinised employment is about 0.13. $\phi$ is defined as the share of routine employment over all employment. We use the National Statistics Socio-economic classification (NS-SEC) developed by ONS. $\phi$ is the share of NS-SEC 7, routine occupations over the rest: NS-SEC 1: Higher managerial, administrative and professional occupations, NS-SEC 2: Lower managerial, administrative and professional occupations, NS-SEC 3: Intermediate occupations, NS-SEC 4: Small employers and own account workers, NS-SEC 5: Lower supervisory and technical occupations, NS-SEC 6: Semi-routine occupations, NS-SEC 7: Routine occupations

${ }^{10}$ We do not expect the dependent variables (change in employment variables from 2001 to 2011) to affect the level of routinisation in 2001, captured by the dummy variable $\phi$.

${ }^{11}$ In what follows, we measure the initial output share of industries using the turnover. We re-run our estimates using the initial employment share of industries. Results, reported in Appendix D, are consistent with those presented below.
} 
TTWA.

We proceed in two steps. First we estimate the aggregate changes in industry R\&D that will be used to predict $R \& D$ at the local level. We estimate the following equation:

$$
\ln R D_{f j t}=\alpha+\ln \text { Employees }_{f}+\theta_{j}+\theta_{t}+\varepsilon_{f j t}
$$

Where $R D_{f j t}$ is the intramural $R \& D$ expenditure of firm $f$, in year $t$. Employees $j$ is the number of employees in the firm, $\theta_{t}$ is a year dummy, while $\theta_{j}$ is a industry dummy. We include data for the years 2000, 2001 and 2002 to estimate the average R\&D firm expenditure in 2001 at the relevant industry. Likewise, we use data from years 2010, 2011 and 2012 to estimate the average R\&D firm expenditure in 2011 at the industry level.

We use 2-digits industry level (i.e. divisions) as classified by SIC 2003.

The estimated set of coefficients for each industry in each period, $\hat{\theta}_{j}$ is our measure of average $R \& D$ expenditure in the industry. The aggregate change in $R \& D$ average expenditure by industry, for the relevant TTWA $i$, is defined as:

$$
\Delta R D_{-i j}=\hat{\theta}_{j, 2011}-\hat{\theta}_{j, 2001}
$$

The subscript $-i$ indicates that we have excluded the relevant TTWA in the estimation of aggregate changes in industry R\&D.

The second step requires the construction of the instrument, which is defined by the following equation:

$$
z_{i}=\Sigma_{j} \omega_{i j} * \Delta R D_{-i j}
$$

For each TTWA $i$ we first estimate the share of output by industry using the 2-digit UK SIC code (2000 version): $\omega_{i j}$. Second, we estimate $\Delta R D_{-i j}$, which is the change in the average R\&D expenditure at the industry level, excluding the TTWA $i^{12}$.

\footnotetext{
${ }^{12}$ We estimate the following equation: $\ln R D_{j-i t}=\alpha+\ln$ Employees $+\theta_{j}+\theta_{t}+\varepsilon_{j-i t} . \hat{\theta}_{j}$ recovers the industry average R\&D expenditure. Again, we use three years data for each period 2001 and 2011. Finally, $\Delta R D_{-i j}=$ $\hat{\theta}_{-i j, 2011}-\hat{\theta}_{-i j, 2001}$
} 
Figure 5 shows the heterogenity of TTWA-level investments in R\&D (as resulting from our IV strategy).

[Figure 5 around here]

In urban economics this strategy isolates labour demand shocks and is known as shiftshare. It was originally implemented by Bartik (1991) and Blanchard and Katz (1992). Baum-Snow and Ferreira (2015) provide a insightful summary of the papers that use the methodology. Recent applications of this identification strategy can be found in Hornbeck and Moretti (2015), Notowidigdo (2013), Guerrieri et al. (2013), Notowidigdo (2013), Bartik (2014) , Diamond (2016).

\section{Results}

\subsection{The Effect of R\&D Investment on the Composition of Employment}

Table 2 reports the baseline estimates. Column 1 shows the results of the first stage estimation and proves the validity of our instrumenting strategy, with an F statistics (123.8) well above the standard threshold. Columns 2-7 present the baseline aggregate evidence of the effect of local R\&D investments over the period 2001-2011.

A $10 \%$ increase in the average R\&D per employee leads to $0.9 \%$ reduction in population, $1.1 \%$ reduction in employment and $1 \%$ reduction in unemployment. Interestingly, the three coefficients are of similar magnitude. R\&D seems to lead to a decline in population in the same proportion for employed and unemployed, which leaves the rate employed/unemployed unaltered.

From 2001 to 2011 the average TTWA increased population by $7.8 \%$, while employment grew by $14.4 \%$ and unemployment grew by $44 \%$. These intercensal changes across TTWAs are evidence of an important geographical re-shuffling of population within the UK. Our estimated effects of R\&D on population, employment and unemployment as proportion of the mean are $11.5 \%$ for population, $7.6 \%$ for employment and $2 \%$ of unemployment. Within an spatial equilibrium setting, these results suggest that R\&D growth explains important parts of the labour mobility within the UK. On the aggregate, the negative effects on population, employment and unemployment are an indication of displacement of workers for new opportunities in low R\&D TTWAs.

[Table 2 around here]

As anticipated in Section 1, the initial employment structure and routinisation of workforce might be relevant to explain the large heterogeneity of the main relationship under scrutiny here across local labour markets. We distinguish between TTWAs with an initial high vs. low share of routinisation of the workforce. In terms of population, TTWAs with

low initial routine share account for $85 \%$ of population, while TTWAs with a large share 
of routinised employment account for $15 \%$ of population. Most people live in non-routine areas (as measured in 2001). Table 3 shows that the effect of R\&D on population and employment occurs mainly in TTWA with a low level of initial routinised employment. For the TTWAs with larger levels of initial routinised employment R\&D increases the population, employment while reducing unemployment. There is no effect on unemployment in the TTWAs with low levels of initial routinsed employment. Taken together these results they suggest that although on overall the employment and unemployment effect are similar, there are important differences depending on the initial level of routinisation: TTWAs with a large share of routine employment in 2001 experienced employment growth as a result of R\&D growth.

\section{[Table 3 around here]}

To investigate what kind of employment is created in routinised local labour markets and what kind of jobs are destroyed in non-routinised TTWAs as a result of R\&D investment we disentangle this effect by sector of activity and skills. Table 15 reports the estimates of the overall effect of R\&D investments in the different sectors (Panel a) and the effect distinguished by degree of routinisation of the workforce (Panel b).

\section{[Table 4 around here]}

Interestingly, when looking at different sectors, the spatial heterogeneity emerges very strongly. Across areas, the effect of increases in R\&D is generally negative in services, particularly in the construction sector, and, albeit with a lower intensity, in non tradable services such as retail and tourism (hotel, accommodation and food) as well as in the public sector, education, arts and entertainment industries (panel a $)^{13}$.

However, when we distinguish by areas (panel b), the effect of R\&D increases in highly routinised areas in 2001 is strongly negative (-0.46) on the manufacturing jobs. Within these areas, the loss of manufacturing jobs is offset by job creation in the service sectors. The increase of R\&D investment seems to have triggered de-industrialisation (or tertiarisation) of areas which were already initially dense in highly routinised workforce. We observe an increase in the employment in all the non tradable sectors: transport (0.40), construction $(0.48)$, wholesale and retail trade (0.40). Also, in areas characterised by high routinisation, R\&D investments create jobs in the business services sectors (e.g. real estate, administrative and technical services as well as in the financial and insurance activities). ${ }^{14}$ Finally, we observe a reduction of employment in the public, education and arts sectors. This resonates with what suggested by (e.g. Mazzolari and Ragusa; 2013; Moretti; 2010b), who find that an increase in low skilled services occur in association with increase in investments in ICTs, albeit they do not consider a spatially fine-grained analysis.

\footnotetext{
${ }^{13}$ Labour composition across sectors is reported in table 13

${ }^{14}$ Unfortunately, the data at our disposal do not allow us to distinguish between knowledge intensive business services from other business services.
} 
A rather different picture emerges when looking at the effect in non-routinised areas, where we observe the opposite effect: local shocks in R\&D investments increase jobs in the manufacturing sector. Non routinised areas see increases in innovation having a negative effect on the employment in the same non tradable services and construction that instead increase in highly routinised areas. Surprisingly, we observe that over the considered period, R\&D does not trigger any significant effect on business services in non-routinised areas.

These results complement the available evidence on the complementarity / substitutability of routinised jobs and technological change (Autor et al.; 2003; Goos and Manning; 2007a, e.g.), pointing to important implications in terms of structural and sectoral transformations induced by innovation. In local labour markets where technological change has not led to a strong replacement of routinised jobs yet, further innovation investments trigger a de-industrialisaiton process, which does not occur -and in fact is reversed-in areas that have been already subject to a reduction of routinised employment.

We now zoom into the skill-content of jobs created and destroyed, and look at the effect of R\&D on the skill composition of employment (Table 5). Overall, this evidence supports very much the sectoral findings above.

\section{[Table 5 around here]}

The weight of $\Delta R D \times \phi$ in the sum of the $\Delta R D+\Delta R D \times \phi$ coefficients is about one seventh: so the overall effect of $R \& D$ on the ratio is $0.20-0.04=0.16$. In other words we find that $R \& D$ increases the number of low skilled jobs, relative to high skilled, in areas that initially have a large number of routinised jobs. If we combine the evidence discussed above in terms of sectoral specificity, we infer that in non-routinsed areas the positive effect of R\&D is notably concentrated on the manufacturing, high-skilled employment, whereas the lowskilled employment created in routinised areas is most likely concentrated in non-tradable sectors and services. These results confirm our conjecture that the spatial heterogeneity in the UK in terms of initial employment structure of local labour markets is responsible for a substantial part of the polarisation effect of innovation in terms of sectoral structural transformation (highly routinised areas see in increase in the workforce in sectors that are dense in routinised jobs, i.e. non tradable services, and non routinise areas mainly see an increase in manufacturing jobs. This is also very much in line with the evidence reported by Autor and Dorn (2013a) in the US and by Goos and Manning (2007b); Goos et al. (2014a) in the EU and the UK at the level of countries. This evidence is also in line with (Moretti; 2010b; Mazzolari and Ragusa; 2013).

\subsection{The Effect of R\&D Investment on Self-Employment and Firm Dy- namics}

As anticipated in Section 1, the effect of innovation on local labour markets may result from the decision of individuals to resort to self-employment. There may be an increase of entrepreneurial ventures following rent opportunities from technical change or, conversely, 
an increase of 'survival' self-employed trying to cope with temporary or definitive exclusion from the (paid) labour market. We test this by decomposing the effect of R\&D on employment between employees and self-employed (Table 6).

[Table 6 around here]

We find that, on average, an increase in R\&D reduces both employees and self-employed (Cols. 1 \& 2) (as already noted in Table 2), but the effect is stronger on self-employed, resulting in an increase in the ratio between employees and self-employed (Col. 3). However, once again, the effect is significantly different in highly routinised areas, where an increase in R\&D increases the number of self-employed with respect to employees. This evidence suggests that in these areas, R\&D creates skills mismatches and changes in current and expected labour demand that lead individuals to resort to self-employment as an alternative to paid employment. This also qualifies the type of employment created in routinised areas as a result of local investments in innovation, which concentrates in low-skilled jobs, non-tradable sectors and services and largely led by a surge in self-employment.

We decompose the effect of R\&D by age cohorts, for both employees and self employed (Table 7). We find that, on average, $R \& D$ reduces paid employment mainly for the middle cohorts (25-34), whereas the youngest (16-24) increase their presence in the (paid) labour market only marginally and the oldest (35-64) decrease only marginally.

[Table 7 around here]

Again the effect of R\&D depends on the initial workforce composition. In particular we observe that in highly routinised areas, very young cohorts (16-24) lose jobs as a result of R\&D increases. These jobs are not replaced by self-employment. The large increase in self-employment in highly routinised areas (which we noticed above from Table 6), is concentrated in individuals between 25 and 34 years old. For older cohorts (35-64) R\&D has a positive effect on both employees and self-employed.

Overall, an increase in R\&D has effects that can be summarised as follows: it reduces employment and self-employment ${ }^{15}$, but increases the demand of skilled workers. Important differences emerge when considering the different initial routinisation of the workforce. In local labour markets with a high rate of routinised workers, an increase in R\&D tends to: increase employment in non-tradable and service sectors and the demand of low-skilled workers. This employment is mainly explained by an increase self-employment, particularly in the age cohort that is mostly negatively hit by R\&D shocks (25-34). In this case, it is hard to consider trends towards self-employment as an 'entrepreneurial renaissance'. This trend is more likely a shift to self-employment dictated by necessity (Manyika et al.; 2016). In what follows, we shed some lights on this latter aspect.

\footnotetext{
${ }^{15}$ The contraction of the overall unemployment, see Table 2, must be attributed to a reduction of the active population due to increased R\&D investments
} 
Given the relevance of self-employment as an alternative occupational choice that emerges due to local R\&D shocks, we investigate the type of ventures that are created in different TTWAs. Table 8 and Table 9 provide insights on the firms dynamics engendered by local investments in innovation looking at the number of firms by size, and their weight in terms of employment, respectively.

Table 8 shows that, despite the large increase in self-employment in routinised areas, the number of registered firms ${ }^{16}$ is barely significantly affected, with a weakly significant impact on micro firms, 1-3 employees, only. The average size of companies in routinised areas is also decreasing, given that only micro firms increase their employment weight (Table 9).

[Tables 8 and 9 around here]

In non-routinised areas, in addition to micro enterprises, also small ones (4-10 employees) increase in number (Table 8) and employment weight (Table 9). Also large companies $(100+$ employees) experience an increase in the employment (Table 9). Overall, although more research is sought that can look more closely at the organisational structure of the new ventures created as a result of local shocks in R\&D investment, our result point to interesting insights. In particular, the surge of self-employment in routinised areas appears to lead to the creation of micro enterprises, possibly not registered ones, and thus to the resemblance of "unincorporated" entrepreneurship (Levine and Rubinstein; 2017) that emerges as a survival decisions of individuals responding to skills mismatches and variation in the labour demand associated to R\&D investment (Thurik et al.; 2008a; Vona and Consoli; 2015b).

\section{Conclusions}

This paper adds a three-fold contribution to the most recent evidence on the effects of innovation on employment. It considers investment in R\&D rather than capital and ICT investments in the belief that these best represent innovation strategy that are likely to require a choice in terms of resource allocation; it extends the analysis from paid employment to self-employment; it considers potential compensation mechanisms at the level of local labour markets. The empirical evidence is based on the British TTWAs.

First, R\&D entails a specific firm investment strategy that requires adjustments in terms of labour and skill demand. It is argued and shown that the impact of R\&D shocks on the labour market go well beyond the distinction between the job enhancing effect of product innovation and the job-displacing effect of process innovation.

\footnotetext{
${ }^{16}$ To carry out this analysis we rely on the Business Structure Database (BSD). BSD includes information on firms that are registered for VAT and operate a PAYE scheme http://doc.ukdataservice.ac. uk/doc/6697/mrdoc/pdf/6697_user_guide.pdf (last accessed: November 2017). At the time of the writing, VAT registration is compulsory when the annual turnover exceeds 85,000 GBP https://www.gov.uk/ vat-registration-thresholds, while PAYE scheme may not be operated if no employee is paid 113 GBP or more a week, get expenses and benefits, or have another job or get a pension. Hence, a typical unregistered company has a limited turnover and no employees (or employees on zero-hour contracts or with a limited number of hours in their contracts.
} 
Second, the compensation mechanisms that the literature has put forward might be more complex than the increasing demand via falling prices that process innovation is argued to allow. The occurrence of compensation mechanisms can be detected by looking at different levels of analysis and have privileged the local labour market. A further reason why we believe it is important to look at the local labour market is that Britain, which we focus on, has peculiarities in terms of industrial structure and spatial polarisation.

Third, as innovation might represent a wealth of new technological opportunities, or have a radically disruptive effect on the (low skilled) workforce, we have argued that a thorough account of the local labour market effects of R\&D should go beyond the paid employment and include self-employment.

Our results indicate that $R \& D$ investments have a significant impact on employment growth mainly in TTWA with a higher concentration of routinised occupations. In terms of skills, innovation seems to spur a positive effect on the composition of employment (more high-skilled jobs) in TTWAs that are already specialised in non-routinised occupations, while a negative effect (more low-skilled jobs) on the composition of employment in areas with more routinised jobs. This confirms that a certain degree of path-dependency characterises the effect of technical change on employment. The additional employment in routinised areas is concentrated in non-tradable service sectors and is fed by an increase in self-employment. We inferred that R\&D would require more coping strategy to face job dismissal rather than create technological opportunities. This effect is concentrated in young age cohort (25-34) and low skilled individuals.

Our findings confirm that the short term effect of R\&D in local labour markets that are already specialised in routinised jobs might result in a harsher polarisation of the job market. The most difficult challenge for policy makers is to formulate a concerted strategy that aims at steering local labour market upgrading in areas that are characterised by routinised jobs, most likely those that are specialised in mature (manufacturing) industries. While most policy implications in the labour economics literature point to issues of training and education, most especially for the young, we also believe it is crucial to assist people in job reconversion, the hardest the most aged is the individual. Technical change might require high skilled people all along the production cycle: however, creativity and adaptation are qualities and talents that are indispensable too, and that should be harnessed regardless the level of education, and most of all socially protected.

The potential negative effects of R\&D investments in private firms on the employment (and self-employment) in local labour market could represent a particularly challenging conundrum for innovation and industrial policy, within the larger perspective of a UK Industrial Strategy (see the HM Government Green Paper on 'Building our Industrial Strategy'). The trade-off of ensuring continuous support to investments in R\&D - most especially in regions that require substantial investments to shift from traditional manufacturing to Industry 4.0, for instance - might need to be counterbalanced by policies of re-training, training and job-protection to tackle the job loss or job-precarisation resulting from innovation. The continuing support to firms investing in R\&D should not be questioned, and further coupled with public investments and procurement in basic science. This however should be accompanied by awareness on how to facilitate and promote reju- 
venation of mature industries in the regions (TTWAs) where a higher shares of routinised workforce is concentrated. While the innovation and industrial policy measures above pertain to the demand side of the skill landscape as a whole, the supply side of skills should be considered a priority. In this respect, the HM Government Green Paper on 'Building our Industrial Strategy' has rightly put forward the need of focusing on Further Education (FE) for the 16-19 cohort. However, as we have shown, the objective of developing skills cannot be limited to this. A concerted platform that includes FE, HE, Continuing Education (CE) and advanced apprenticeships that reduce the burden of access to HE and that upgrade the upper technical skills in disadvantaged regions is to be envisaged. Particularly in the latter areas, Lifelong Learning (LL) and CE should put in place feasible programmes of retraining and re-skilling, possibly in the mature age cohorts.

The present work paves the way to a number of extensions, which mainly entail the analysis of the wage distribution effects of R\&D shocks across TTWAs. Within the context of boosting UK productivity within a concerted industrial strategy, it is fundamental also to look at which wage deciles and occupational categories, including self-employed across the UK, mostly gain from productivity shocks. 


\section{References}

Acemoglu, Daron and David Autor, "Skills, tasks and technologies: Implications for employment and earnings," in David Card and Orley Ashenfelter, eds., Handbook of Labor Economics, Vol. 4, Elsevier, 2011, pp. 1043-1171.

Adams, Stuart, Helen Miller, and Thomas Pope, "Tax, legal form and the gig economy in: The IFS Green Budget," Technical Report, Institute of Fiscal Studies, 2017.

Aghion, Philippe, Ufuk Akcigit, Antonin Bergeaud, Richard Blundell, and David Hémous, “Innovation and Top Income Inequality," jun 2015.

Autor, David and David Dorn, "The Growth of Low-Skill Service Jobs and the Polarization of the US Labor Market," American Economic Review, 2013, 103 (5), 1553-1597.

Autor, David H and David Dorn, "The Growth of Low-Skill Service Jobs and the Polarization of the US Labor Market," American Economic Review, aug 2013, 103 (5), 1553-1597.

Autor, David H., David Dorn, Lawrence F. Katz, Christina Patterson, and John Van Reenen, "Concentrating on the Fall of the Labor Share," 2017.

${ }_{-},,_{-},,_{-}$, and $\ldots$, "The Fall of the Labour Share and the Rise of Superstar Firms," Technical Report, Massachusetts Institute of Technology 2017.

_, Frank Levy, and Richard J. Murnane, "The Skill Content of Recent Technological Change: An Empirical Exploration," The Quarterly Journal of Economics, 2003, 118 (4), 1279-1333.

Autor, David H, Lawrence F Katz, and Melissa S Kearney, "Trends in U.S. Wage Inequality: Re-Assessing the Revisionists," sep 2005.

Autor, D.H. and A. Salomons, "Robocalypse Now - Does Productivity Growth Threaten Employment?," Technical Report, European Central Bank Forum conference proceedings. 2017.

Balaran, Brhmie, Josie Warden, and Wallace-Stephens Fabian, "Good Gigs. A fairer future for the UK's gig economy," Technical Report, Royal Society of Arts 2017.

Bartik, Timothy J., Who Benefits from State and Local Economic Development Policies?, W.E. Upjohn Institute for Employment Research, 1991.

_ , "How Effects of Local Labor Demand Shocks Vary with Local Labor Market Conditions," Upjohn Working Papers and Journal Articles 14-202, W.E. Upjohn Institute for Employment Research January 2014.

Baum-Snow, Nathaniel and Fernando Ferreira, "Chapter 1 - Causal Inference in Urban and Regional Economics," in Gilles Duranton, J. Vernon Henderson, and William C. Strange, eds., Handbook of Regional and Urban Economics, Vol. 5 of Handbook of Regional and Urban Economics, Elsevier, 2015, pp. 3 - 68. 
Berger, Thor and Carl Benedikt Frey, "Did the Computer Revolution shift the fortunes of U.S. cities? Technology shocks and the geography of new jobs," Regional Science and Urban Economics, mar 2016, 57, 38-45.

Blanchard, Olivier Jean and Lawrence F. Katz, "Regional Evolutions," Brookings Papers on Economic Activity, 1992, 23 (1), 1-76.

Bloom, Nicholas, Charles I JOnes, John Van Reenen, and Michael Webb, "Are Ideas Getting Harder to Find?," Technical Report, NBER Working Paper No. 237822017.

Bresnahan, Timothy F and Manuel Trajtenberg, "General purpose technologies 'Engines of growth'?," Journal of Econometrics, 1995, 65 (21), 83-108.

Brynjolfsson, Erik and Andrew McAfee, Race Against the Machine: How the Digital Revolution is Accelerating Innovation, Driving Productivity, and Irreversibly Transforming Employment and the Economy, Digital Frontier Press, 2012.

_ and _ , The Second Machine Age: Work, Progress, and Prosperity in a Time of Brilliant Technologies, New York: W. W. Norton \& Company, 2014.

Calvino, F. and M.E. Virgillito, “The Innovation-Employment Nexus: A Critical Survey of Theory and Empirics," Technical Report, ISIGrowth Working Paper 9/2016 2016.

Cincera, Michele and Veugelers Rheinilde, "Differences in the rates of return to R\&D for European and US young leading R\&D firms," Research Policy 43, 1413-1421, 2014.

Crawford, Claire, Wenchao Jin, and Helen Simpson, "Firms' productivity, investment and training: what happened during the recession and how was it affected by the national minimum wage?," Technical Report R76, The IFS, London mar 2013.

Dachs, Bernhard, Martin Hud, Christian Koehler, and Bettina Peters, "Employment Effects of Innovations over the Business Cycle : Firm-Level Evidence from European Countries," 2016.

Davis, Richard B. Freeman Barth Erling James C. and Andrew J. Wang, "The Effects of Scientists and Engineers on Productivity and Earnings at the Establishment where they work," Technical Report, National Bureau of Economic Research Working Paper 23484 2017.

Diamond, Rebecca, “The Determinants and Welfare Implications of US Workers' Diverging Location Choices by Skill: 1980-2000," American Economic Review, March 2016, 106 (3), 479-524.

Echeverri-Carroll, Elsie and Sofia G. Ayala, "Wage differentials and the spatial concentration of high-technology industries," Papers in Regional Science, 2009, 88 (3), 623-641.

Faggio, Giulia, Kjell G. Salvanes, and John van Reenen, "The evolution of inequality in productivity and wages: Panel data evidence," Industrial and Corporate Change, 2010, 19 (6), 1919-1951. 
Fleck, Susan, John Glaser, and Shawn Sprague, "The compensation-productivity gap: a visual essay," Monthly Labor Review, 2011, (January), 57-69.

Freeman, Chris and Luc Soete, Technical Change and Full Employment, Oxford: Basil Blackwell., 1987.

Freeman, Christopher, John Clark, and Luc Soete, Unemployment and technical innovation: a study of long waves and economic development, Frances Pinter, 1982.

Frey, Carl Benedikt and Michael A. Osborne, "The future of employment: how susceptible are jobs to computerisation?," 2013.

_ and _ , Technology at work. the Future of Innovation and Employment number February, Citi GPS, 2015.

Gallegati, Mauro Marco, Mauro Marco Gallegati, James B. Ramsey, and Willi Semmler, "Productivity and unemployment: a scale-by-scale panel data analysis for the G7 countries," Studies in Nonlinear Dynamics \& Econometrics, jan 2015.

Goos, Maarten, Alan Manning, and Anna Salomons, "Explaining Job Polarization: Routine-Biased Technological Change and Offshoring," American Economic Review, August 2014, 104 (8), 2509-26.

${ }_{-},{ }_{-}$, and _ , "Explaining Job Polarization: Routine-Biased Technological Change and Offshoring," American Economic Review, aug 2014, 104 (8), 2509-2526.

_ and _ , "Lousy and Lovely Jobs: The Rising Polarization of Work in Britain," Review of Economics and Statistics, feb 2007, 89 (1), 118-133.

_ and _ , "Lousy and Lovely Jobs: The Rising Polarization of Work in Britain," The Review of Economics and Statistics, February 2007, 89 (1), 118-133.

Graetz, Georg and Guy Michaels, "Robots at work," 2015.

Griliches, Zvi, "Issues in assessing the contribution and development of research to productivity growth," The Bell Journal of Economics, 1979, 10 (1), 92-116.

Guerrieri, Veronica, Daniel Hartley, and Erik Hurst, "Endogenous gentrification and housing price dynamics," Journal of Public Economics, 2013, 100 (C), 45-60.

Haldane, Andrew G, “Work, Wages and Monetary Policy,” 2017.

Hall, Bronwyn, Francesca Lotti, and Jacques Mairesse, "Employment, innovation, and productivity: Evidence from Italian microdata.," Industrial and Corporate Change 17, 81339., 2008.

_ , Jacques Mairesse, and Pierre Mohnen, "Measuring the returns to R\&D," in "Handbook of the Economics of Innovation," Elsevier, 2010.

Hornbeck, Richard and Enrico Moretti, "Who Benefit from Productivity Growth? The Local and Aggregate Effect of Local TFP Shocks on Wages, Rent and Inequality," Mimeo, 2015. 
Karabarbounis, L. and B. Neiman, "The Global Decline of the Labor Share," The Quarterly Journal of Economics, oct 2013, 129 (1), 61-103.

Katz, Lawrence and Alan Krueger, "The Rise and Nature of Alternative Work Arrangements in the United States, 1995-2015," sep 2016.

Kenney, Martin and John Zysman, "The Rise of the Platform Economy," Technical Report, Issues in Science and Technology http:/ / issues.org/32-3/the-rise-of-the-platformeconomy/ 2016.

Ker, Daniel and Matthew Greenaway, "Coverage of the Business Enterprise Research \& Development Survey," Technical Report, Office of National Statistics 2012.

Korpi, M., "Does size of local labour markets affect wage inequality? a rank-size rule of income distribution," Journal of Economic Geography, oct 2007, 8 (2), 211-237.

Levine, Ross and Yona Rubinstein, "Smart and Illicit: Who Becomes an Entrepreneur and Do They Earn More?," The Quarterly Journal of Economics, Volume 132, Issue 2, 1 May 2017, Pages 963-1018, 2017.

Manyika, James, Susan Lund, Jacues Bughi, Kelsey Robinson, Jan Mischke, and Deepa Mahajan, "Independent Work: Choice, Necessity and the Gig Economy," Technical Report, McKinsey Global Institute 2016.

Matano, A. and P. Naticchioni, "Wage distribution and the spatial sorting of workers," Journal of Economic Geography, jun 2011, 12 (2), 379-408.

Mazzolari, Francesca and Giuseppe Ragusa, "Spillovers from High-skill Consumption to Low-Skill Labour Markets," The Review of Economics and Statistics 95(1):74-86, 2013.

Meliciani, V. and M. Savona, "The determinants of regional specialisation in business services: agglomeration economies, vertical linkages and innovation," Journal of Economic Geography, jan 2014, 15 (2), 387-416.

Moretti, Enrico, "Local multipliers," American Economic Review, 2010, 100 (2), 373-377.

_ , "Local Multipliers," American Economic Review, May 2010, 100 (2), 373-77.

Notowidigdo, Matthew, "The Incidence of Local Labor Demand Shocks," Mimeo, Northwestern University 2013.

Pessoa, João Paulo and John Van Reenen, “The UK productivity and jobs puzzle: Does the answer lie in wage flexibility?," Economic Journal, may 2014, 124 (576), 433-452.

Piva, Mariacristina and Marco Vivarelli, "Is R\&D Good for Employment? Microeconometric Evidence from the EU," Technical Report, IZA Discussion Papers, No. 105812017.

Powell, Walter W., Kenneth W. Koput, James I. Bowie, and Laurel Smith-Doerr, "The Spatial Clustering of Science and Capital: Accounting for Biotech Firm-Venture Capital Relationships," Regional Studies, may 2002, 36 (3), 291-305. 
Åstebro Jing Chen, Peter Thompson Thomas, "Stars and Misfits: Self-Employment and Labor Market Frictions," Management Science 57(11):1999-2017, 2011.

Sachs, Jeffrey D, Seth G Benzell, and Guillermo LaGarda, "Robots: Curse or Blessing? A Basic Framework," apr 2015.

Saint-Paul, Gilles, Innovation and Inequality: How Does Technical Progress Affect Workers?, Princeton University Press, 2008.

Summers, Lawrence H., "Economic Possibilities for Our Children," NBER Reporter, dec 2013, $2013(4), 1$.

Thurik, A. Roy, Martin A. Carree, André van Stel, and David B. Audretsch, "Does selfemployment reduce unemployment?," Journal of Business Venturing, 2008, 23 (6), 673-686.

_ , _ , AndrÃ $(\mathcal{C}$ van Stel, and David B. Audretsch, "Does self-employment reduce unemployment?," Journal of Business Venturing 23 673-686, 2008.

Van Reenen, John, "Wage inequality, technology and trade: 21st century evidence," Labour Economics, dec 2011, 18 (6), 730-741.

Vona, Francesco and Davide Consoli, "Innovation and skill dynamics: a life-cycle approach," Industrial and Corporate Change, 2015, 24 (6), 1393-1415.

_ and _ , "Innovation and skill dynamics: a life-cycle approach," Industrial and Corporate Change, dec 2015, 24 (6), 1393-1415. 


\section{A Figures}

Figure 1: Business R\&D expenditure as share of GDP

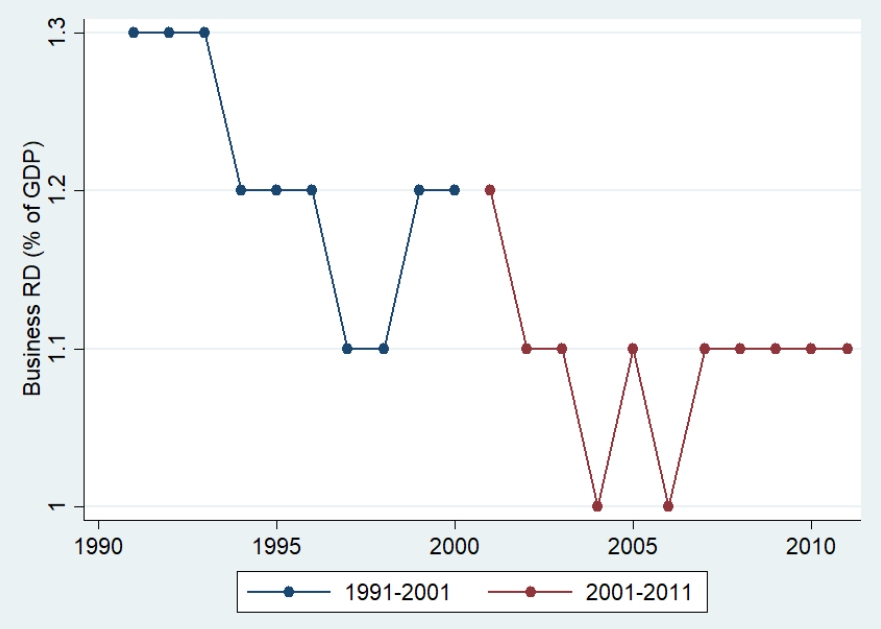

Data source: ONS

Figure 2: Annual TFP Growth

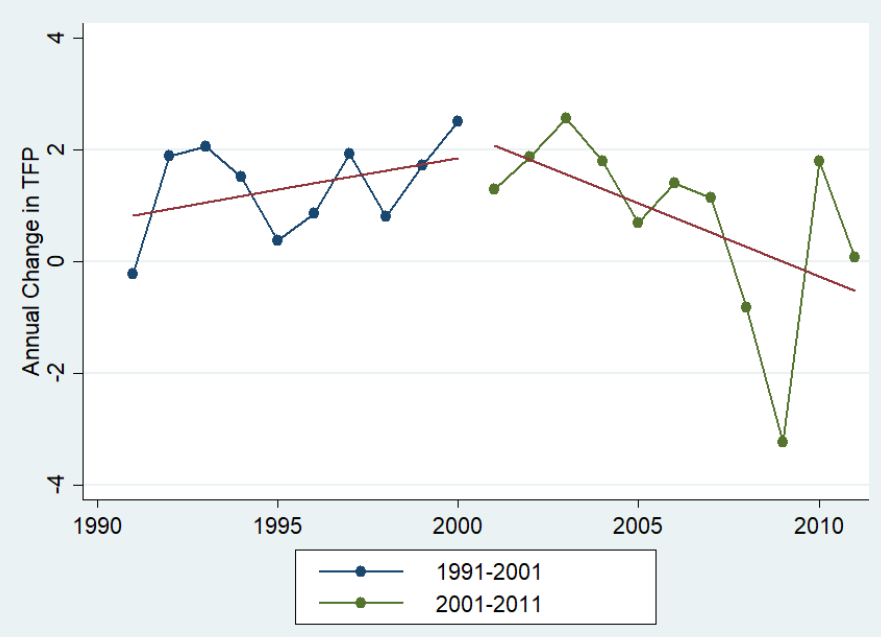

Data source: ONS 
Figure 3: Trends of Employment, Unemployment and Self-Employment in the UK, 19912013

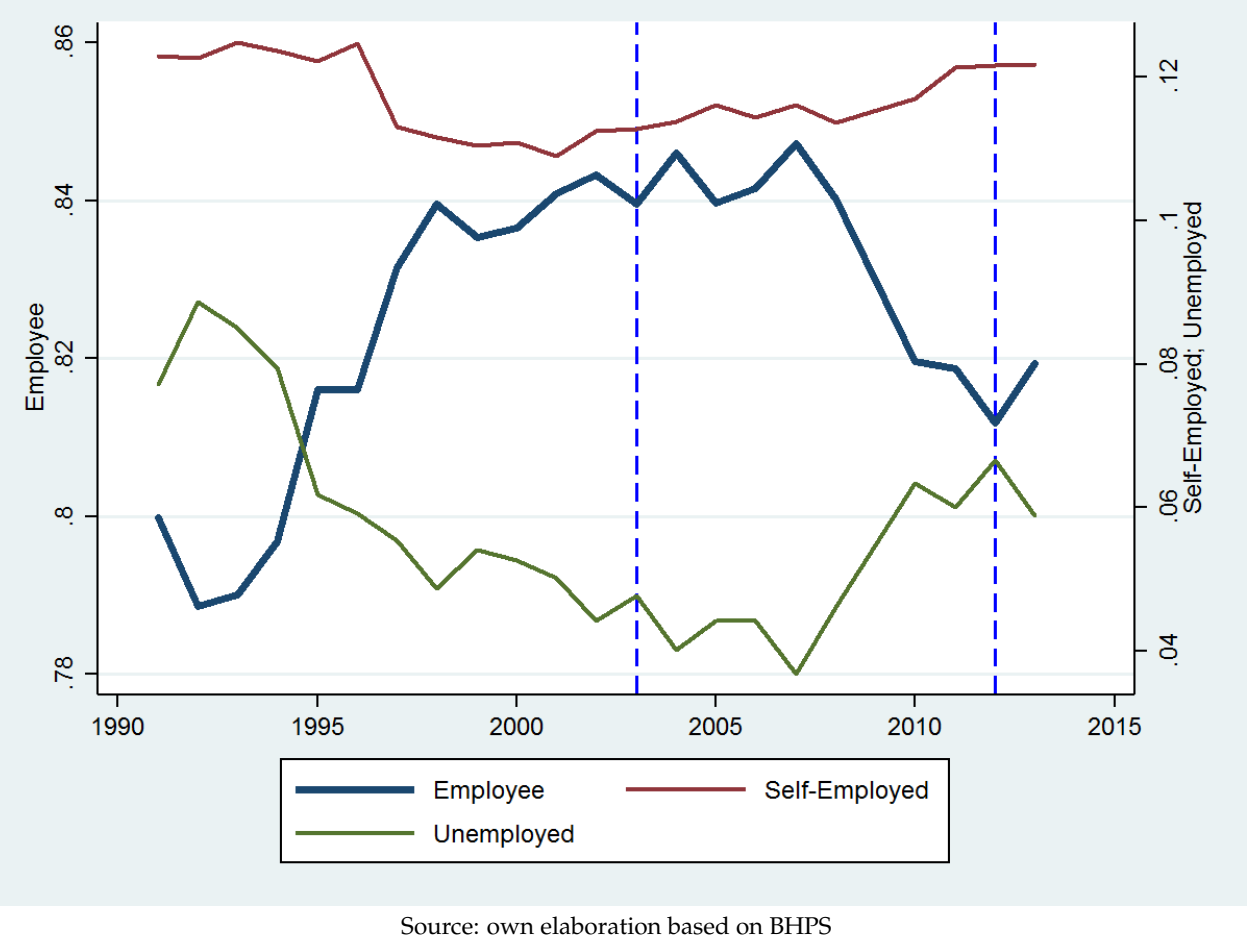


Figure 4: Share of Routine Employment across British TTWAs, 2001

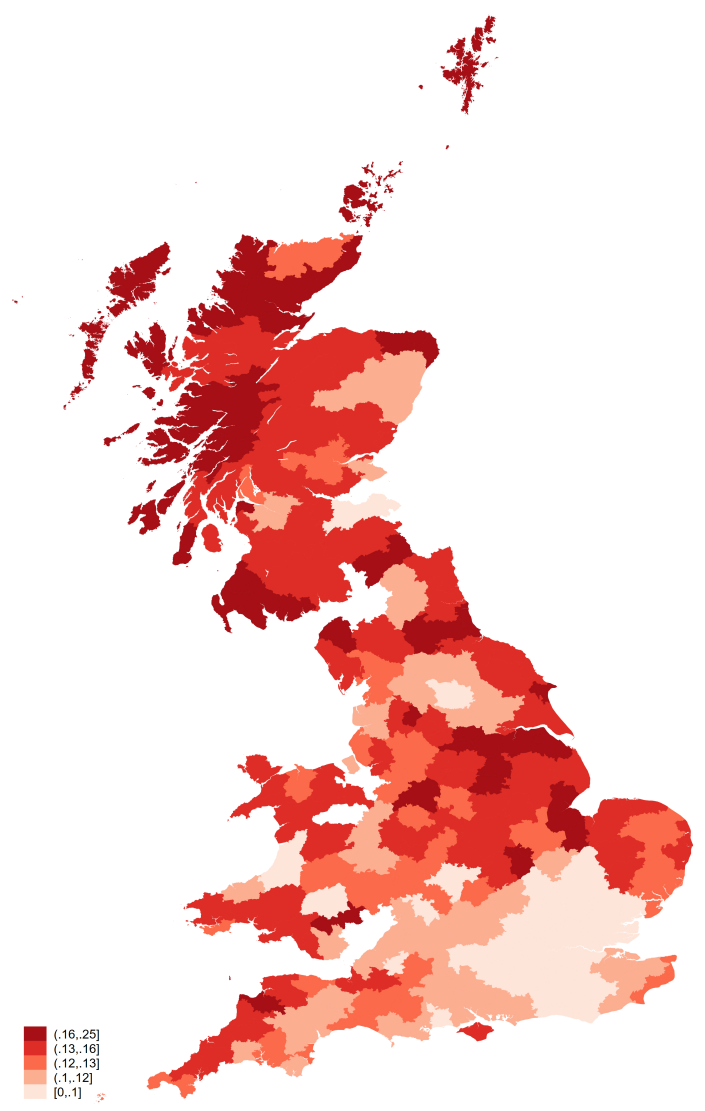

Each TTWA reports the labor share of category NS-Sec 7, Routine Occupations. 
Figure 5: R\&D investments across British TTWAs, 2001

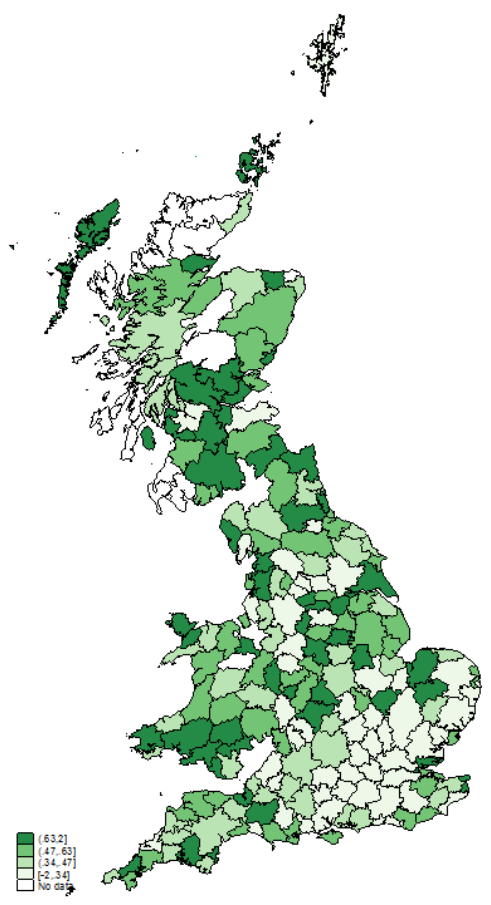

Own elaboration based on BERD

Figure 6: Change in employment rate vs initial employment rate
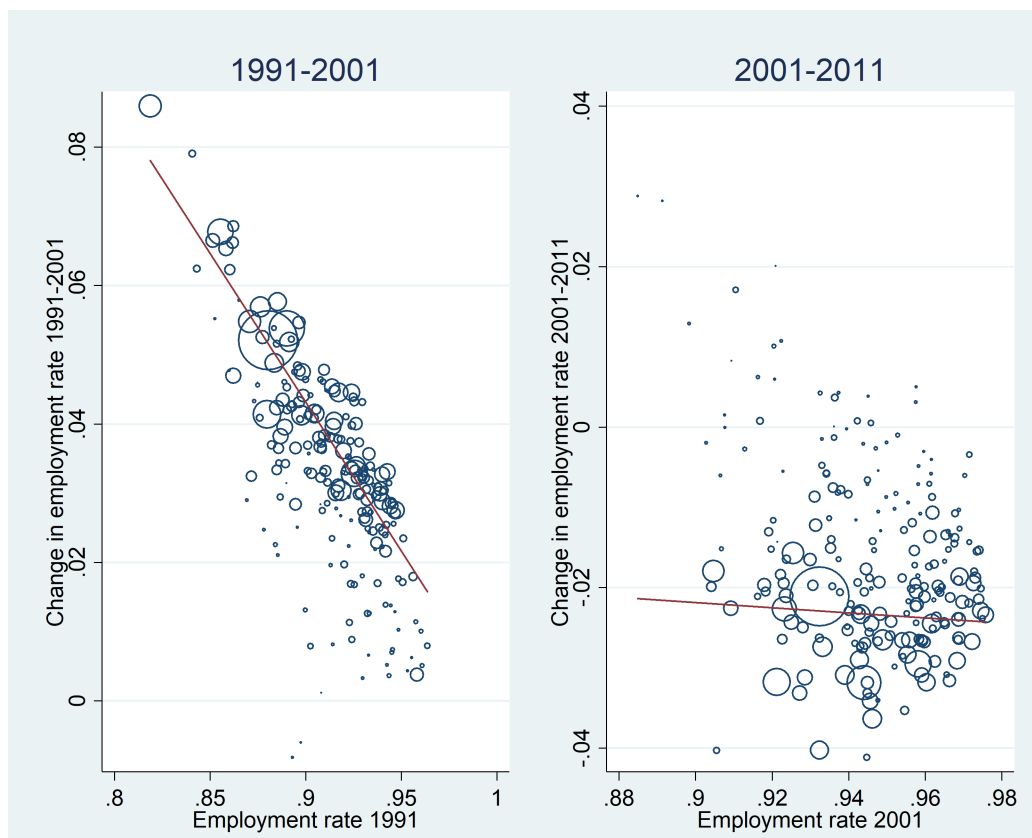

Notes: [1] Data source: Population census 1991, 2001 and 2011. [2] The unit of observation is the TTWA based on 2011 boundaries for 212 TTWAs from England, Scotland and Wales. [3] Each observation is weighted by the TTWA's population in the base year of each panel. 
Figure 7: Change in Employment rate and employment growth vs change in R\&D
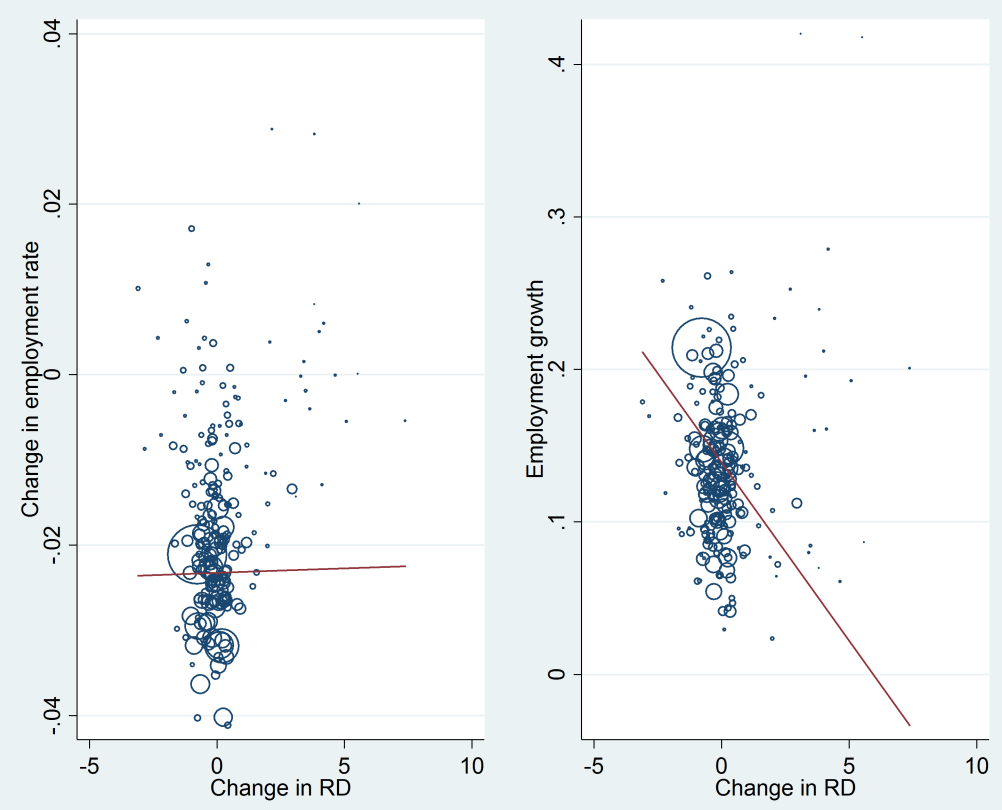

Figure 8: Employment growth vs change in R\&D by Routine
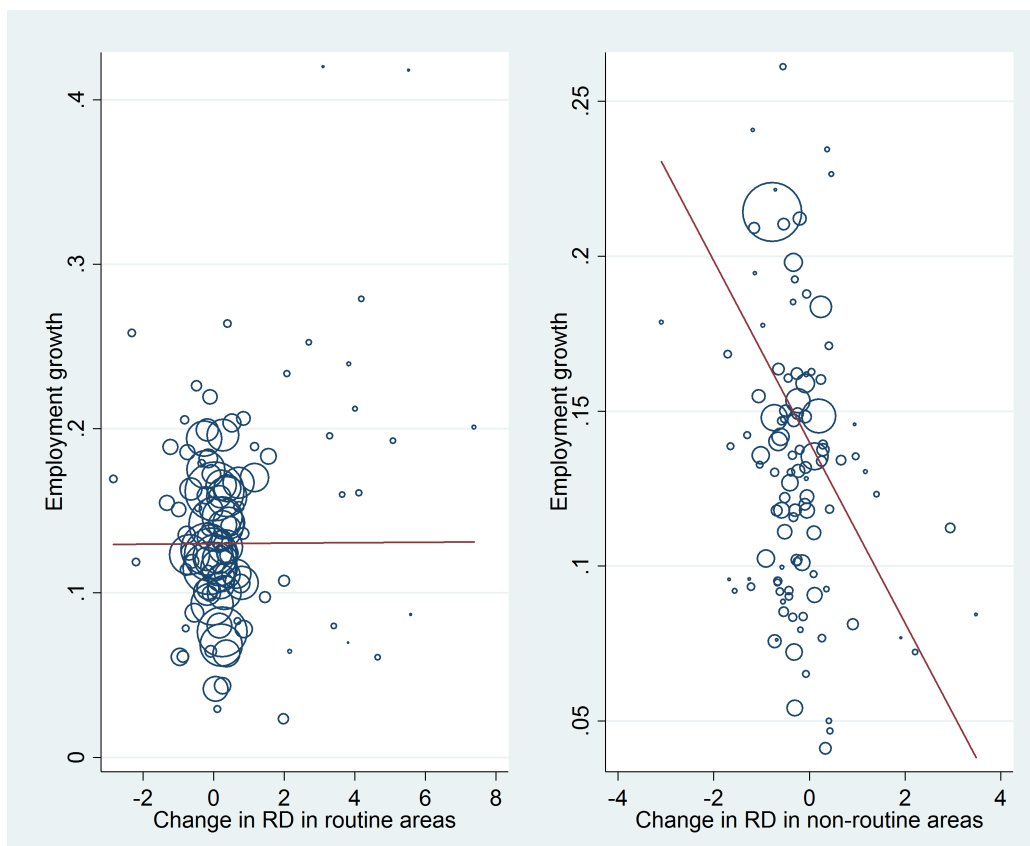


\section{B Tables}

Table 1: Share of Routinised Labour: Bottom and Top TTWAs in 2001

\begin{tabular}{lc}
\hline \hline TTWA & $\phi$ \\
\hline Bottom 5: least routinised & \\
Reading & .0680643 \\
Guildford and Aldershot & .0691688 \\
London & .0721267 \\
Crawley & .072558 \\
Brighton & .0735549 \\
& \\
Average & .1353318 \\
Median & .1335365 \\
& \\
Top 5: most routinised & \\
Fraserburgh & .2338129 \\
Corby & .2335603 \\
Hawick and Kelso & .226953 \\
Girvan & .2176792 \\
Mansfield & .1980037 \\
\hline
\end{tabular}

Notes: [1] $\phi$ is defined as the share of routine employment over all employment. We use the National Statistics Socio-economic classification (NS-SEC) developed by ONS. $\phi$ is the share of NS-SEC 7, routine occupations over the rest: NS-SEC 1: Higher managerial, administrative and professional occupations, NS-SEC 2: Lower managerial, administrative and professional occupations, NS-SEC 3: Intermediate occupations, NS-SEC 4: Small employers and own account workers, NS-SEC 5: Lower supervisory and technical occupations, NS-SEC 6: Semi-routine occupations, NS-SEC 7: Routine occupations

Table 2: The effect of R\&D on employment: baseline results

\begin{tabular}{lccccccc}
\hline \hline & First Stage & Pop. & \multicolumn{2}{c}{ Employment } & \multicolumn{2}{c}{ Unemployment } & Ratio \\
& $\Delta R D$ & $\operatorname{Ln}(\mathrm{P})$ & $\operatorname{Ln}(\mathrm{E})$ & $\operatorname{Ln}(\mathrm{E} / \mathrm{P})$ & $\operatorname{Ln}(\mathrm{U})$ & $\operatorname{Ln}(\mathrm{U} / \mathrm{P})$ & $\operatorname{Ln}(\mathrm{E} / \mathrm{U})$ \\
& $(1)$ & $(2)$ & $(4)$ & $(4)$ & $(5)$ & $(6)$ & $(7)$ \\
\hline$\Delta R D$ & & $-0.09^{* * *}$ & $-0.08^{* * *}$ & 0.00 & $-0.10^{* * *}$ & -0.02 & 0.02 \\
& & $(0.01)$ & $(0.02)$ & $(0.01)$ & $(0.03)$ & $(0.04)$ & $(0.05)$ \\
Predicted RD & $0.82^{* * *}$ & & & & & & \\
& $(0.07)$ & & & & & & \\
F-test & 123.80 & & & & & & \\
$R^{2}$ & 0.15 & & & & & & \\
Obs. & 212 & 212 & 212 & 212 & 212 & 212 \\
\hline
\end{tabular}

Notes: [1] First column reports first stage estimates. [2] Population, employment and unemployment considers individuals between 16 and 64 only. [3] All regressions include country dummies and errors are clustered at country level. [4] Coefficients that are statistically significant are denoted by the following system: ${ }^{*} 10 \%, * * 5 \%$ and ${ }^{* * *} 1 \%$ 
Table 3: The effect of R\&D on employment: routinised and non routinised TTWAs

\begin{tabular}{lcccccc}
\hline \hline & Pop. & \multicolumn{2}{c}{ Employment } & \multicolumn{2}{c}{ Unemployment } & Ratio \\
& $\operatorname{Ln}(\mathrm{P})$ & $\operatorname{Ln}(\mathrm{E})$ & $\operatorname{Ln}(\mathrm{E} / \mathrm{P})$ & $\operatorname{Ln}(\mathrm{U})$ & $\operatorname{Ln}(\mathrm{U} / \mathrm{P})$ & $\operatorname{Ln}(\mathrm{E} / \mathrm{U})$ \\
\hline \multirow{3}{*}{$\Delta R D$} & $(1)$ & $(2)$ & $(4)$ & $(4)$ & $(5)$ & $(6)$ \\
& $-0.09^{* * *}$ & $-0.11^{* * *}$ & -0.01 & -0.01 & 0.08 & -0.09 \\
$\Delta R D \times \phi$ & $(0.01)$ & $(0.03)$ & $(0.01)$ & $(0.04)$ & $(0.06)$ & $(0.07)$ \\
& $0.04^{* *}$ & $0.20^{* * *}$ & $0.15^{* * *}$ & $-0.71^{* * *}$ & $-0.76^{* * *}$ & $0.91^{* * *}$ \\
Obs. & $(0.02)$ & $(0.08)$ & $(0.06)$ & $(0.21)$ & $(0.23)$ & $(0.28)$ \\
& 212 & 212 & 212 & 212 & 212 & 212 \\
\hline
\end{tabular}

Notes: [1] First column reports first stage estimates. [2] Population, employment and unemployment considers individuals between 16 and 64 only. [3] All regressions include country dummies and errors are clustered at country level. [4] Coefficients that are statistically significant are denoted by the following system: ${ }^{*} 10 \%,{ }^{*} 5 \%$ and ${ }^{* * *} 1 \%$

Table 4: The Effect of R\&D on employment, by industry

\begin{tabular}{|c|c|c|c|c|c|c|}
\hline & Manufacturing & Construction & Transport & $\begin{array}{l}\text { Wholesale, retail, } \\
\text { accommodation, } \\
\text { food } \\
\text { (4) }\end{array}$ & $\begin{array}{l}\text { Business and } \\
\text { financial services } \\
\text { (5) }\end{array}$ & $\begin{array}{c}\text { Public sector, } \\
\text { education, } \\
\text { arts and entert. } \\
\text { (6) }\end{array}$ \\
\hline \multicolumn{7}{|c|}{ a. Baseline } \\
\hline \multirow[t]{2}{*}{$\Delta R D$} & $0.29^{* * *}$ & $-0.12^{* * *}$ & $0.23^{* * *}$ & $-0.08^{* * *}$ & $0.04^{* * *}$ & $-0.01^{* *}$ \\
\hline & $(0.03)$ & $(0.05)$ & $(0.02)$ & $(0.02)$ & $(0.01)$ & $(0.01)$ \\
\hline Obs. & 212 & 212 & 212 & 212 & 212 & 212 \\
\hline \multicolumn{7}{|c|}{ b. By TTWA routinisaiton } \\
\hline \multirow[t]{2}{*}{$\Delta R D$} & $0.35^{* * *}$ & $-0.18^{* * *}$ & $0.18^{* * * *}$ & $-0.13^{* * *}$ & -0.04 & 0.00 \\
\hline & $(0.01)$ & $(0.05)$ & $(0.01)$ & $(0.02)$ & $(0.02)$ & $(0.01)$ \\
\hline \multirow{2}{*}{$\Delta R D \times \phi$} & $-0.46^{* * *}$ & $0.48^{* * *}$ & $0.40^{* * *}$ & $0.40^{* * *}$ & $0.59^{* * *}$ & $-0.13^{* * *}$ \\
\hline & $(0.17)$ & $(0.08)$ & $(0.12)$ & $(0.06)$ & $(0.15)$ & $(0.03)$ \\
\hline Obs. & 212 & 212 & 212 & 212 & 212 & 212 \\
\hline
\end{tabular}

Notes to table 15: [1] Calculations include only individuals from 16 to 64. [2] All regressions include country dummies and errors are clustered at country level. [3] Coefficients that are statistically significant are denoted by the following system: ${ }^{*} 10 \%, * * 5 \%$ and ${ }^{* * *} 1 \%$

Table 5: The effect of R\&D on employment, by skills

\begin{tabular}{|c|c|c|c|}
\hline & $\begin{array}{c}\mathrm{Ln}(\mathrm{H}) \\
(1)\end{array}$ & $\begin{array}{l}\operatorname{Ln}(\mathrm{L}) \\
(2)\end{array}$ & $\begin{array}{c}\operatorname{Ln}(\mathrm{H} / \mathrm{L}) \\
\text { (3) }\end{array}$ \\
\hline \multicolumn{4}{|c|}{ a. Baseline } \\
\hline$\Delta R D$ & $\begin{array}{c}0.13^{* * *} \\
(0.01)\end{array}$ & $\begin{array}{l}-0.04 \\
(0.02)\end{array}$ & $\begin{array}{c}0.16^{* * * *} \\
(0.04)\end{array}$ \\
\hline Obs. & 212 & 212 & 212 \\
\hline \multicolumn{4}{|c|}{ b. By TTWA routinisation } \\
\hline$\Delta R D$ & $\begin{array}{c}0.12^{* * * *} \\
(0.01)\end{array}$ & $\begin{array}{c}-0.07^{* *} \\
(0.03)\end{array}$ & $\begin{array}{c}0.20^{* * * *} \\
(0.04)\end{array}$ \\
\hline$\Delta R D \times \phi$ & $\begin{array}{c}0.03 \\
(0.05)\end{array}$ & $\begin{array}{c}0.31^{* * *} \\
(0.08)\end{array}$ & $\begin{array}{c}-0.28^{* * *} \\
(0.08)\end{array}$ \\
\hline Obs. & 212 & 212 & 212 \\
\hline
\end{tabular}

Notes: [1] All dependent variables are log changes in the TTWA from 2001 to 2011. Column 1 is the number of high skilled individuals. Column 2 is the number of low skilled individuals, while column 3 is the ratio among these two numbers [2] High skill = level 4 or more for England and Wales, and levels 3 or above for Scotland. Low skilled $=$ any lower than high skilled [3] Calculations include only individuals from 16 to 64. [4] All regressions include country dummies and errors are clustered at country level. [5] Coefficients that are statistically significant are denoted by the following system:: ${ }^{*} 10 \%$, ${ }^{* *} \%$ and ${ }^{* * *} 1 \%$ 
Table 6: The effect of R\&D on paid employment and self-employment

\begin{tabular}{|c|c|c|c|c|c|c|}
\hline & \multicolumn{3}{|c|}{ By Emp. Type } & \multirow{2}{*}{\multicolumn{3}{|c|}{$\begin{array}{c}\text { Ratio in (3) } \\
\text { by age group }\end{array}$}} \\
\hline & \multirow{2}{*}{$\begin{array}{c}\text { Employee } \\
\operatorname{Ln}\left(E_{E}\right) \\
(1)\end{array}$} & \multirow{2}{*}{$\begin{array}{l}\text { Self-Emp. } \\
\operatorname{Ln}\left(E_{S E}\right) \\
\quad(2)\end{array}$} & \multirow{2}{*}{$\begin{array}{c}\text { Ratio } \\
\operatorname{Ln}\left(\frac{E_{E}}{E_{S E}}\right) \\
\text { (3) }\end{array}$} & & & \\
\hline & & & & $\begin{array}{c}16-24 \\
(4)\end{array}$ & $\begin{array}{c}25-34 \\
(5)\end{array}$ & $\begin{array}{c}35-65 \\
(6)\end{array}$ \\
\hline a. Baseline & & & & & & \\
\hline$\Delta R D$ & $\begin{array}{c}-0.06^{* * *} \\
(0.02)\end{array}$ & $\begin{array}{c}-0.17^{* * *} \\
(0.03)\end{array}$ & $\begin{array}{c}0.11^{* * *} \\
(0.01)\end{array}$ & $\begin{array}{c}0.32^{* * *} \\
(0.02)\end{array}$ & $\begin{array}{c}0.19^{* * *} \\
(0.03)\end{array}$ & $\begin{array}{c}0.07^{* * * *} \\
(0.00)\end{array}$ \\
\hline b. By TTW & A routinisa & & & & & \\
\hline$\Delta R D$ & $\begin{array}{c}-0.08^{* * *} \\
(0.03)\end{array}$ & $\begin{array}{c}-0.22^{* * *} \\
(0.03)\end{array}$ & $\begin{array}{c}0.14^{* * *} \\
(0.01)\end{array}$ & $\begin{array}{c}0.41^{* * *} \\
(0.02)\end{array}$ & $\begin{array}{c}0.23^{* * *} \\
(0.02)\end{array}$ & $\begin{array}{l}0.08^{* * * *} \\
(0.01)\end{array}$ \\
\hline$\Delta R D \times \phi$ & $\begin{array}{l}0.15^{*} \\
(0.08)\end{array}$ & $\begin{array}{c}0.45^{* * *} \\
(0.08)\end{array}$ & $\begin{array}{c}-0.30^{* * * *} \\
(0.09)\end{array}$ & $\begin{array}{c}-0.77^{* * * *} \\
(0.25)\end{array}$ & $\begin{array}{c}-0.36^{* * *} \\
(0.13)\end{array}$ & $\begin{array}{l}-0.10^{* *} \\
(0.04)\end{array}$ \\
\hline
\end{tabular}

Notes: [1] [3] Coefficients that are statistically significant are denoted by the following system: ${ }^{*} 10 \%, * * 5 \%$ and $* * * 1 \%$

Table 7: The effect of R\&D on paid and self-employment, by age cohorts

\begin{tabular}{|c|c|c|c|c|c|c|}
\hline & \multicolumn{2}{|c|}{$16-24$} & \multicolumn{2}{|c|}{$25-34$} & \multicolumn{2}{|c|}{$35-64$} \\
\hline & $\begin{array}{c}\operatorname{Ln}\left(E_{k}\right) \\
(1)\end{array}$ & $\begin{array}{l}\frac{E_{k}}{E} \\
(2)\end{array}$ & $\begin{array}{c}\operatorname{Ln}\left(E_{k}\right) \\
(3)\end{array}$ & $\begin{array}{c}\frac{E_{k}}{E} \\
(4)\end{array}$ & $\begin{array}{c}\operatorname{Ln}\left(E_{k}\right) \\
\quad(5)\end{array}$ & $\begin{array}{c}\frac{E_{k}}{E} \\
(6)\end{array}$ \\
\hline \multicolumn{7}{|c|}{ a. Employee } \\
\hline \multicolumn{7}{|c|}{ Baseline } \\
\hline$\Delta R D$ & $\begin{array}{l}0.03^{*} \\
(0.02)\end{array}$ & $\begin{array}{c}0.01^{* * *} \\
(0.00)\end{array}$ & $\begin{array}{c}-0.21^{* * *} \\
(0.03)\end{array}$ & $\begin{array}{c}-0.03^{* * *} \\
(0.00)\end{array}$ & $\begin{array}{l}-0.03 \\
(0.02)\end{array}$ & $\begin{array}{c}0.02^{* * *} \\
(0.00)\end{array}$ \\
\hline \multicolumn{7}{|c|}{ By TTWA routinisation } \\
\hline$\Delta R D$ & $\begin{array}{c}0.12^{* * *} \\
(0.01)\end{array}$ & $\begin{array}{c}0.03^{* * *} \\
(0.00)\end{array}$ & $\begin{array}{c}-0.25^{* * *} \\
(0.05)\end{array}$ & $\begin{array}{c}-0.04^{* * *} \\
(0.01)\end{array}$ & $\begin{array}{c}-0.06^{* * *} \\
(0.02)\end{array}$ & $\begin{array}{c}0.01^{* * *} \\
(0.00)\end{array}$ \\
\hline$\Delta R D \times \phi$ & $\begin{array}{c}-0.69^{* * *} \\
(0.17)\end{array}$ & $\begin{array}{c}-0.12^{* * *} \\
(0.02)\end{array}$ & $\begin{array}{c}0.32^{*} \\
(0.20)\end{array}$ & $\begin{array}{c}0.04 \\
(0.03)\end{array}$ & $\begin{array}{c}0.28^{* * *} \\
(0.03)\end{array}$ & $\begin{array}{l}0.08^{* *} \\
(0.03)\end{array}$ \\
\hline Obs. & 212 & 212 & 212 & 212 & 212 & 212 \\
\hline \multicolumn{7}{|c|}{ b. Self-Employed } \\
\hline$\triangle R D$ & $\begin{array}{c}-0.29^{* * *} \\
(0.01)\end{array}$ & $\begin{array}{c}-0.01^{* * * *} \\
(0.00)\end{array}$ & $\begin{array}{c}-0.39^{* * *} \\
(0.06)\end{array}$ & $\begin{array}{c}-0.04^{* * *} \\
(0.01)\end{array}$ & $\begin{array}{c}-0.10^{* * *} \\
(0.02)\end{array}$ & $\begin{array}{c}0.05^{* * *} \\
(0.01)\end{array}$ \\
\hline \multicolumn{7}{|c|}{ By TTWA routinisation } \\
\hline$\Delta R D$ & $\begin{array}{c}-0.30^{* * *} \\
(0.01)\end{array}$ & $\begin{array}{c}-0.01^{* * *} \\
(0.00)\end{array}$ & $\begin{array}{c}-0.48^{* * * *} \\
(0.07)\end{array}$ & $\begin{array}{c}-0.05^{* * *} \\
(0.01)\end{array}$ & $\begin{array}{c}-0.14^{* * *} \\
(0.02)\end{array}$ & $\begin{array}{c}0.06^{* * * *} \\
(0.01)\end{array}$ \\
\hline$\Delta R D \times \phi$ & $\begin{array}{c}0.08 \\
(0.11)\end{array}$ & $\begin{array}{c}-0.01^{* * * *} \\
(0.00)\end{array}$ & $\begin{array}{c}0.68^{* * *} \\
(0.22)\end{array}$ & $\begin{array}{l}0.05^{* *} \\
(0.03)\end{array}$ & $\begin{array}{c}0.38^{* * * *} \\
(0.04)\end{array}$ & $\begin{array}{l}-0.05^{*} \\
(0.03)\end{array}$ \\
\hline
\end{tabular}

Notes: [1] All dependent variables are log changes in the TTWA from 2001 to 2011. Column 1 includes the number of workers who are employee or self employed, indexed by $\mathrm{k}$, within the 16-24 age cohort, column 2 is the ratio of this category among all employed individuals within the 16-24 age cohort. Columns 3 to 6 replicate this structire for the other two remaining cohorts. [2] All regressions include country dummies and errors are clustered at country level. [3] Coefficients that are statistically significant are denoted by the following system: ${ }^{*} 10 \%,{ }^{*} 5 \%$ and ${ }^{* * *} 1 \%$ 
Table 8: The effect of R\&D on the number of firms, by size

\begin{tabular}{|c|c|c|c|c|c|}
\hline & $\begin{array}{l}1-3 \\
(1)\end{array}$ & $\begin{array}{c}4-10 \\
(2)\end{array}$ & $\begin{array}{c}11-50 \\
(3)\end{array}$ & $\begin{array}{c}51-100 \\
(4)\end{array}$ & $\begin{array}{c}101+ \\
(5)\end{array}$ \\
\hline \multicolumn{6}{|c|}{ a. Baseline } \\
\hline$\Delta R D$ & $\begin{array}{c}0.14^{* * *} \\
(0.00)\end{array}$ & $\begin{array}{c}0.09^{* * *} \\
(0.00)\end{array}$ & $\begin{array}{c}-0.02 \\
(0.02)\end{array}$ & $\begin{array}{c}-0.03 \\
(0.03)\end{array}$ & $\begin{array}{c}0.03 \\
(0.03)\end{array}$ \\
\hline Obs. & 212 & 212 & 211 & 205 & 197 \\
\hline \multicolumn{6}{|c|}{ b. By TTWA routinisation } \\
\hline$\triangle R D$ & $\begin{array}{c}0.10^{* * *} \\
(0.02)\end{array}$ & $\begin{array}{l}0.06^{* *} \\
(0.02)\end{array}$ & $\begin{array}{l}-0.06 \\
(0.05)\end{array}$ & $\begin{array}{l}-0.06 \\
(0.10)\end{array}$ & $\begin{array}{c}0.04 \\
(0.08)\end{array}$ \\
\hline$\Delta R D \times \phi$ & $\begin{array}{l}0.31^{*} \\
(0.17)\end{array}$ & $\begin{array}{c}0.23 \\
(0.19)\end{array}$ & $\begin{array}{c}0.33 \\
(0.28)\end{array}$ & $\begin{array}{c}0.27 \\
(0.61)\end{array}$ & $\begin{array}{c}-0.10 \\
(0.39)\end{array}$ \\
\hline Obs. & 212 & 212 & 211 & 205 & 197 \\
\hline
\end{tabular}

Notes to table 8: [1] Calculations include only firms reported alive or death for less than two years. Some TTWAs did not report large firms. [2] All regressions include country dummies and errors are clustered at country level. [3] Coefficients that are statistically significant are denoted by the following system: ${ }^{*} 10 \%,{ }^{* * 5} \%$ and ${ }^{* * *} 1 \%$

Table 9: The effect of R\&D on firms employment, by size

\begin{tabular}{|c|c|c|c|c|c|c|}
\hline & $\begin{array}{c}\text { Size } \\
(1)\end{array}$ & $\begin{array}{l}1-3 \\
(2)\end{array}$ & $\begin{array}{c}4-10 \\
\text { (3) }\end{array}$ & $\begin{array}{c}11-50 \\
(4)\end{array}$ & $\begin{array}{c}51-100 \\
(5)\end{array}$ & $\begin{array}{c}100+ \\
(6)\end{array}$ \\
\hline \multicolumn{7}{|l|}{ a. Baseline } \\
\hline \multirow[t]{2}{*}{$\Delta R D$} & -0.00 & $0.14^{* * *}$ & $0.08^{* * *}$ & -0.03 & -0.03 & 0.17 \\
\hline & $(0.08)$ & $(0.00)$ & $(0.00)$ & $(0.02)$ & $(0.02)$ & $(0.11)$ \\
\hline Obs. & 212 & 212 & 212 & 211 & 205 & 196 \\
\hline \multicolumn{7}{|c|}{ b. By By TTWA routinisation } \\
\hline \multirow[t]{2}{*}{$\triangle R D$} & 0.06 & $0.10^{* * *}$ & $0.05^{* *}$ & -0.08 & -0.07 & $0.26^{* * *}$ \\
\hline & $(0.05)$ & $(0.02)$ & $(0.02)$ & $(0.05)$ & $(0.10)$ & $(0.05)$ \\
\hline \multirow[t]{2}{*}{$\Delta R D \times \phi$} & $-0.48^{* *}$ & $0.29^{* *}$ & 0.19 & 0.36 & 0.27 & -0.76 \\
\hline & $(0.22)$ & $(0.14)$ & $(0.17)$ & $(0.29)$ & $(0.62)$ & $(0.61)$ \\
\hline Obs. & 212 & 212 & 212 & 211 & 205 & 196 \\
\hline
\end{tabular}

Notes to table 9: [1] Calculations include only firms reported alive or death for less than two years. Some TTWAs did not report large firms. [2] All regressions include country dummies and errors are clustered at country level. [3] Coefficients that are statistically significant are denoted by the following system: ${ }^{*} 10 \%,{ }^{* *} 5 \%$ and ${ }^{* * *} 1 \%$ 
Table 10: Employment by gender: age group 16-24 only

\begin{tabular}{|c|c|c|c|c|c|c|}
\hline & \multicolumn{3}{|c|}{ Male } & \multicolumn{3}{|c|}{ Female } \\
\hline & $\begin{array}{l}\mathrm{N} \\
(1)\end{array}$ & $\begin{array}{c}E \\
(2)\end{array}$ & $\begin{array}{l}\text { SE } \\
\text { (3) }\end{array}$ & $\begin{array}{l}\mathrm{N} \\
(4)\end{array}$ & $\begin{array}{c}E \\
(5) \\
\end{array}$ & $\begin{array}{l}\text { SE } \\
(6)\end{array}$ \\
\hline \multicolumn{7}{|c|}{ a. Baseline } \\
\hline$\Delta R D$ & $\begin{array}{l}-0.01^{*} \\
(0.00)\end{array}$ & $\begin{array}{c}0.02^{* * *} \\
(0.01)\end{array}$ & $\begin{array}{c}-0.20^{* * *} \\
(0.00)\end{array}$ & $\begin{array}{c}0.04^{* * *} \\
(0.00)\end{array}$ & $\begin{array}{c}0.07^{* * *} \\
(0.00)\end{array}$ & $\begin{array}{c}-0.44^{* * * *} \\
(0.03)\end{array}$ \\
\hline Obs. & 167 & 167 & 167 & 167 & 167 & 166 \\
\hline \multicolumn{7}{|c|}{ b. By TTWA routinisation } \\
\hline$\Delta R D$ & $\begin{array}{c}0.05^{* * *} \\
(0.01)\end{array}$ & $\begin{array}{c}0.09^{* * *} \\
(0.01)\end{array}$ & $\begin{array}{c}-0.17^{* * *} \\
(0.00)\end{array}$ & $\begin{array}{c}0.12^{* * *} \\
(0.01)\end{array}$ & $\begin{array}{c}0.16^{* * *} \\
(0.02)\end{array}$ & $\begin{array}{c}-0.54^{* * * *} \\
(0.03)\end{array}$ \\
\hline$\Delta R D \times \phi$ & $\begin{array}{c}-0.49^{* * *} \\
(0.13)\end{array}$ & $\begin{array}{c}-0.52^{* * *} \\
(0.15)\end{array}$ & $\begin{array}{c}-0.21^{* * *} \\
(0.03)\end{array}$ & $\begin{array}{c}-0.66^{* * *} \\
(0.14)\end{array}$ & $\begin{array}{c}-0.72^{* * *} \\
(0.16)\end{array}$ & $\begin{array}{c}0.85^{*} \\
(0.50)\end{array}$ \\
\hline Obs. & 167 & 167 & 167 & 167 & 167 & 166 \\
\hline
\end{tabular}

Notes to table 10: [1] All dependent variables are log changes in the number of workers in the TTWA from 2001 to 2011. Columns 1 and 4 are totals (male and female), columns 2 and 5 are employees only (male and female) while columns 3 and 6 are self-employed only (male and female) [2] Calculations include only individuals from 16 to 24. [3] All regressions include country dummies and errors are clustered at country level. [4] Coefficients that are statistically significant are denoted by the following system: ${ }^{*} 10 \%,{ }^{* * 5 \%}$ and ${ }^{* * *} 1 \%$

Table 11: Employment by gender: age group 25-34 only

\begin{tabular}{|c|c|c|c|c|c|c|}
\hline & \multicolumn{3}{|c|}{ Male } & \multicolumn{3}{|c|}{ Female } \\
\hline & $\begin{array}{l}N \\
(1)\end{array}$ & $\begin{array}{c}E \\
(2)\end{array}$ & $\begin{array}{l}\text { SE } \\
\text { (3) }\end{array}$ & $\begin{array}{l}N \\
(4)\end{array}$ & $\begin{array}{c}E \\
(5)\end{array}$ & $\begin{array}{l}\text { SE } \\
\text { (6) }\end{array}$ \\
\hline \multicolumn{7}{|c|}{ a. Baseline } \\
\hline$\Delta R D$ & $\begin{array}{c}-0.26^{* * *} \\
(0.01)\end{array}$ & $\begin{array}{c}-0.26^{* * *} \\
(0.01)\end{array}$ & $\begin{array}{c}-0.39^{* * *} \\
(0.01)\end{array}$ & $\begin{array}{c}-0.20^{* * *} \\
(0.01)\end{array}$ & $\begin{array}{c}-0.19^{* * * *} \\
(0.01)\end{array}$ & $\begin{array}{c}-0.54^{* * *} \\
(0.01)\end{array}$ \\
\hline Obs. & 167 & 167 & 167 & 167 & 167 & 167 \\
\hline \multicolumn{7}{|c|}{ b. By TTWA routinisation } \\
\hline$\triangle R D$ & $\begin{array}{c}-0.32^{* * *} \\
(0.01)\end{array}$ & $\begin{array}{c}-0.33^{* * *} \\
(0.01)\end{array}$ & $\begin{array}{c}-0.51^{* * *} \\
(0.02)\end{array}$ & $\begin{array}{c}-0.25^{* * *} \\
(0.01)\end{array}$ & $\begin{array}{c}-0.24^{* * *} \\
(0.01)\end{array}$ & $\begin{array}{c}-0.57^{* * * *} \\
(0.02)\end{array}$ \\
\hline$\Delta R D \times \phi$ & $\begin{array}{c}0.51^{* * *} \\
(0.11)\end{array}$ & $\begin{array}{c}0.57^{* * *} \\
(0.12)\end{array}$ & $\begin{array}{l}1.01^{* * *} \\
(0.28)\end{array}$ & $\begin{array}{c}0.45^{* * *} \\
(0.10)\end{array}$ & $\begin{array}{c}0.45^{* * *} \\
(0.09)\end{array}$ & $\begin{array}{c}0.31 \\
(0.27)\end{array}$ \\
\hline Obs. & 167 & 167 & 167 & 167 & 167 & 167 \\
\hline
\end{tabular}

Notes to table 11: [1] All dependent variables are log changes in the number of workers in the TTWA from 2001 to 2011. Columns 1 and 4 are totals (male and female), columns 2 and 5 are employees only (male and female) while columns 3 and 6 are self-employed only (male and female) [2] Calculations include only individuals from 25 to 34. [3] All regressions include country dummies and errors are clustered at country level. [4] Coefficients that are statistically significant are denoted by the following system: ${ }^{*} 10 \%,{ }^{* * 5 \%}$ and ${ }^{* * *} 1 \%$ 
Table 12: Employment by gender: age group 35-64 only

\begin{tabular}{|c|c|c|c|c|c|c|}
\hline & \multicolumn{3}{|c|}{ Male } & \multicolumn{3}{|c|}{ Female } \\
\hline & $\begin{array}{l}\mathrm{N} \\
(1)\end{array}$ & $\begin{array}{c}E \\
(2)\end{array}$ & $\begin{array}{l}\text { SE } \\
(3)\end{array}$ & $\begin{array}{l}N \\
(4)\end{array}$ & $\begin{array}{c}E \\
(5)\end{array}$ & $\begin{array}{l}\text { SE } \\
(6)\end{array}$ \\
\hline \multicolumn{7}{|c|}{ a. Baseline } \\
\hline$\Delta R D$ & $\begin{array}{c}-0.09^{* * *} \\
(0.00)\end{array}$ & $\begin{array}{c}-0.08^{* * * *} \\
(0.00)\end{array}$ & $\begin{array}{c}-0.07^{* * * *} \\
(0.00)\end{array}$ & $\begin{array}{c}-0.04^{* * *} \\
(0.00)\end{array}$ & $\begin{array}{c}-0.01^{* * *} \\
(0.00)\end{array}$ & $\begin{array}{c}-0.19^{* * *} \\
(0.01)\end{array}$ \\
\hline Obs. & 167 & 167 & 167 & 167 & 167 & 167 \\
\hline \multicolumn{7}{|c|}{ b. By TTWA routinisation } \\
\hline$\Delta R D$ & $\begin{array}{c}-0.13^{* * *} \\
(0.00)\end{array}$ & $\begin{array}{c}-0.12^{* * * *} \\
(0.00)\end{array}$ & $\begin{array}{c}-0.12^{* * *} \\
(0.00)\end{array}$ & $\begin{array}{c}-0.08^{* * *} \\
(0.00)\end{array}$ & $\begin{array}{c}-0.05^{* * *} \\
(0.00)\end{array}$ & $\begin{array}{c}-0.23^{* * *} \\
(0.01)\end{array}$ \\
\hline$\Delta R D \times \phi$ & $\begin{array}{l}0.34^{* * *} \\
(0.04)\end{array}$ & $\begin{array}{c}0.33^{* * *} \\
(0.03)\end{array}$ & $\begin{array}{l}0.41^{* * *} \\
(0.04)\end{array}$ & $\begin{array}{c}0.32^{* * *} \\
(0.03)\end{array}$ & $\begin{array}{c}0.30^{* * *} \\
(0.01)\end{array}$ & $\begin{array}{c}0.38^{* * *} \\
(0.13)\end{array}$ \\
\hline Obs. & 167 & 167 & 167 & 167 & 167 & 167 \\
\hline
\end{tabular}

Notes to table 12: [1] All dependent variables are log changes in the number of workers in the TTWA from 2001 to 2011. Columns 1 and 4 are totals (male and female), columns 2 and 5 are employees only (male and female) while columns 3 and 6 are self-employed only (male and female) [2] Calculations include only individuals from 35 to 64. [3] All regressions include country dummies and errors are clustered at country level. [4] Coefficients that are statistically significant are denoted by the following system: ${ }^{*} 10 \%,{ }^{* * 5} \%$ and ${ }^{* * *} 1 \%$

Table 13: Employment composition by sector

\begin{tabular}{lccc}
\hline \hline & 2001 & 2011 & Change \\
\hline Agriculture & 0.013 & 0.007 & -0.006 \\
Mining & 0.003 & 0.003 & -0.001 \\
Energy & 0.008 & 0.013 & 0.005 \\
Manufacturing & 0.148 & 0.088 & -0.060 \\
Construction & 0.068 & 0.077 & 0.009 \\
Transport & 0.071 & 0.050 & -0.021 \\
Wholesale retail and accommodation & 0.215 & 0.216 & 0.001 \\
Business and financial services & 0.177 & 0.172 & -0.005 \\
Public sector, education and entertainment & 0.297 & 0.375 & 0.077 \\
Total & $\mathbf{1 . 0 0 0}$ & $\mathbf{1 . 0 0 0}$ & \\
\hline
\end{tabular}

Notes to table 13: [1] Data source: 2001 and 2011 census. [2] We used 2003 SIC codes to map across census waves. Agriculture consists of section A and B, mining is section C, energy is section E, manufacturing is section $\mathrm{D}$, construction is section $\mathrm{F}$, transport is section $\mathrm{I}$, wholesales retail and accommodation group section $\mathrm{G}$ and $\mathrm{H}$, business and financial services group sections $\mathrm{J}$ and $\mathrm{K}$, while Public sector, education and entertainment groups sections L, M, N and O. 


\section{Shift-Share Instrument}

\section{Robustness checks}

Table 14: The effect of R\&D on employment: routinised and non routinised TTWAs

\begin{tabular}{|c|c|c|c|c|c|c|}
\hline & \multirow{2}{*}{$\begin{array}{l}\text { Pop. } \\
\text { Ln(P) } \\
(1)\end{array}$} & \multicolumn{2}{|c|}{ Employment } & \multicolumn{2}{|c|}{ Unemployment } & \multirow{2}{*}{$\begin{array}{c}\text { Ratio } \\
\operatorname{Ln}(\mathrm{E} / \mathrm{U}) \\
(6)\end{array}$} \\
\hline & & $\begin{array}{l}\operatorname{Ln}(E) \\
(2)\end{array}$ & $\begin{array}{c}\operatorname{Ln}(E / P) \\
(3)\end{array}$ & $\begin{array}{c}\operatorname{Ln}(U) \\
(4)\end{array}$ & $\begin{array}{c}\operatorname{Ln}(\mathrm{U} / \mathrm{P}) \\
(5)\end{array}$ & \\
\hline \multicolumn{7}{|c|}{ a. Baseline } \\
\hline$\Delta R D$ & $\begin{array}{c}-0.09^{* * *} \\
(0.01)\end{array}$ & $\begin{array}{c}-0.07^{* * * *} \\
(0.01)\end{array}$ & $\begin{array}{c}0.02^{* * *} \\
(0.00)\end{array}$ & $\begin{array}{c}-0.16^{* * * *} \\
(0.01)\end{array}$ & $\begin{array}{c}-0.08^{* * *} \\
(0.01)\end{array}$ & $\begin{array}{c}0.09^{* * *} \\
(0.01)\end{array}$ \\
\hline Obs. & 212 & 212 & 212 & 212 & 212 & 212 \\
\hline \multicolumn{7}{|c|}{ b. By TTWA routinisation } \\
\hline$\Delta R D$ & $\begin{array}{c}-0.09^{* * *} \\
(0.01)\end{array}$ & $\begin{array}{c}-0.09^{* * * *} \\
(0.02)\end{array}$ & $\begin{array}{c}0.00 \\
(0.01)\end{array}$ & $\begin{array}{l}-0.06 \\
(0.06)\end{array}$ & $\begin{array}{c}0.03 \\
(0.07)\end{array}$ & $\begin{array}{l}-0.03 \\
(0.07)\end{array}$ \\
\hline$\Delta R D * \phi$ & $\begin{array}{l}0.05^{* *} \\
(0.03)\end{array}$ & $\begin{array}{c}0.15^{* * *} \\
(0.05)\end{array}$ & $\begin{array}{c}0.10^{* * *} \\
(0.03)\end{array}$ & $\begin{array}{c}-0.78^{* * * *} \\
(0.27)\end{array}$ & $\begin{array}{c}-0.83^{* * * *} \\
(0.28)\end{array}$ & $\begin{array}{c}0.93^{* * *} \\
(0.31)\end{array}$ \\
\hline Obs. & 212 & 212 & 212 & 212 & 212 & 212 \\
\hline
\end{tabular}

Notes to table 14: [1] All dependent variables are log changes in the TTWA from 2001 to 2011. Column 1 is the population size of the TTWA. Columns 2 and 4 are the number of employed and unemployed individuals. Columns 3 and 5 are the ratio of employed and unemployed over population, respectively. Column 6 is the ratio employed over unemployed individuals. [2] Calculations include only individuals from 16 to 64. [3] All regressions include country dummies and errors are clustered at country level. [4] Coefficients that are statistically significant are denoted by the following system: $* 10 \%, * * 5 \%$ and ${ }^{* * *} 1 \%$ 
Table 15: The Effect of R\&D on employment, by industry

\begin{tabular}{|c|c|c|c|c|c|c|}
\hline & Manufacturing & Construction & Transport & $\begin{array}{c}\text { Wholesale, retail, } \\
\text { accommodation, } \\
\text { food } \\
(4) \\
\end{array}$ & $\begin{array}{c}\text { Business and } \\
\text { financial services } \\
\text { (5) }\end{array}$ & $\begin{array}{c}\text { Public sector, } \\
\text { education, } \\
\text { arts and entert. } \\
(6)\end{array}$ \\
\hline \multicolumn{7}{|c|}{ a. Baseline } \\
\hline$\Delta R D$ & $\begin{array}{c}0.29^{* * * *} \\
(0.01)\end{array}$ & $\begin{array}{c}-0.13^{* * * *} \\
(0.02)\end{array}$ & $\begin{array}{c}0.26^{* * *} \\
(0.01)\end{array}$ & $\begin{array}{c}-0.06^{* * * *} \\
(0.01)\end{array}$ & $\begin{array}{c}0.10^{* * * *} \\
(0.01)\end{array}$ & $\begin{array}{c}-0.03^{* * * *} \\
(0.00)\end{array}$ \\
\hline Obs. & 212 & 212 & 212 & 212 & 212 & 212 \\
\hline \multicolumn{7}{|c|}{ b. By TTWA routinisation } \\
\hline$\Delta R D$ & $\begin{array}{c}0.40^{* * *} \\
(0.01)\end{array}$ & $\begin{array}{l}-0.21^{* * *} \\
(0.04)\end{array}$ & $\begin{array}{l}0.18^{* * *} \\
(0.05)\end{array}$ & $\begin{array}{l}-0.09^{* * *} \\
(0.02)\end{array}$ & $\begin{array}{c}0.04 \\
(0.03)\end{array}$ & $\begin{array}{c}-0.07^{* * *} \\
(0.03)\end{array}$ \\
\hline$\Delta R D * \phi$ & $\begin{array}{l}-0.85^{* * *} \\
(0.17)\end{array}$ & $\begin{array}{l}0.65^{* * * *} \\
(0.10)\end{array}$ & $\begin{array}{l}0.59^{*} \\
(0.34)\end{array}$ & $\begin{array}{l}0.26^{* * * *} \\
(0.02)\end{array}$ & $\begin{array}{l}0.42^{* *} \\
(0.20)\end{array}$ & $\begin{array}{l}0.27^{* *} \\
(0.13)\end{array}$ \\
\hline Obs. & 212 & 212 & 212 & 212 & 212 & 212 \\
\hline
\end{tabular}

Notes to table 15: [1] All dependent variables are log changes in the number of workers for each industry in the TTWA from 2001 to 2011. [2] All regressions include country dummies and errors are clustered at country level. [4] Coefficients that are statistically significant are denoted by the following system: ${ }^{*} 10 \%,{ }^{* *} \%$ and ${ }^{* * *} 1 \%$

Table 16: The effect of R\&D on employment, by skills

\begin{tabular}{|c|c|c|c|}
\hline & $\begin{array}{l}\text { High } \\
\operatorname{Ln}(\mathrm{H}) \\
(1)\end{array}$ & $\begin{array}{l}\text { Low } \\
\operatorname{Ln}(\mathrm{L}) \\
(2)\end{array}$ & $\begin{array}{c}\text { Ratio } \\
\operatorname{Ln}(\mathrm{H} / \mathrm{L}) \\
(3)\end{array}$ \\
\hline \multicolumn{4}{|c|}{ a. Baseline } \\
\hline$\Delta R D$ & $\begin{array}{c}0.15^{* * *} \\
(0.01)\end{array}$ & $\begin{array}{c}-0.02^{* *} \\
(0.01)\end{array}$ & $\begin{array}{c}0.17^{* * *} \\
(0.01)\end{array}$ \\
\hline Obs. & 212 & 212 & 212 \\
\hline \multicolumn{4}{|c|}{ b. By TTWA routinisation } \\
\hline$\triangle R D$ & $\begin{array}{c}0.17^{* * *} \\
(0.01)\end{array}$ & $\begin{array}{c}-0.05^{* * *} \\
(0.01)\end{array}$ & $\begin{array}{c}0.22^{* * *} \\
(0.01)\end{array}$ \\
\hline$\Delta R D * \phi$ & $\begin{array}{c}0.00 \\
(0.10)\end{array}$ & $\begin{array}{c}0.09^{* * *} \\
(0.03)\end{array}$ & $\begin{array}{l}-0.09 \\
(0.08)\end{array}$ \\
\hline Obs. & 212 & 212 & 212 \\
\hline
\end{tabular}

Notes to table 16: [1] All dependent variables are log changes of the number of workers in the TTWA from 2001 to 2011. [2] High skill = degree or more while low skill = less than a degree [3] All regressions include country dummies and errors are clustered at country level. [4] Coefficients that are statistically significant are denoted by the following system: ${ }^{*} 10 \%,{ }^{* *} \%$ and ${ }^{* * *} 1 \%$ 
Table 17: The effect of R\&D on paid employment and self-employment

\begin{tabular}{|c|c|c|c|c|c|c|}
\hline & \multicolumn{3}{|c|}{ By Emp. Type } & \multicolumn{3}{|c|}{ Ratio in (3) } \\
\hline & $\begin{array}{c}\text { Employee } \\
\text { Ln(E) } \\
(1)\end{array}$ & $\begin{array}{l}\text { Self-emp. } \\
\text { Ln(SE) } \\
\text { (2) }\end{array}$ & $\begin{array}{c}\text { Ratio } \\
\operatorname{Ln}(\mathrm{E} / \mathrm{SE}) \\
(3)\end{array}$ & $\begin{array}{c}16-24 \\
\operatorname{Ln}(\mathrm{E} / \mathrm{SE}) \\
(4)\end{array}$ & $\begin{array}{c}25-34 \\
\operatorname{Ln}(\mathrm{E} / \mathrm{SE}) \\
(5)\end{array}$ & $\begin{array}{c}35-64) \\
\operatorname{Ln}(\mathrm{E} / \mathrm{SE}) \\
(6)\end{array}$ \\
\hline \multicolumn{7}{|c|}{ a. Baseline } \\
\hline$\Delta R D$ & $\begin{array}{c}-0.05^{* * *} \\
(0.01)\end{array}$ & $\begin{array}{c}-0.16^{* * *} \\
(0.02)\end{array}$ & $\begin{array}{c}0.11^{* * *} \\
(0.01)\end{array}$ & $\begin{array}{c}0.31^{* * *} \\
(0.03)\end{array}$ & $\begin{array}{c}0.20^{* * *} \\
(0.02)\end{array}$ & $\begin{array}{c}0.07^{* * *} \\
(0.01)\end{array}$ \\
\hline Obs. & 212 & 212 & 212 & 212 & 212 & 212 \\
\hline \multicolumn{7}{|c|}{ b. By TTWA routinisation } \\
\hline$\triangle R D$ & $\begin{array}{c}-0.05^{* * *} \\
(0.01)\end{array}$ & $\begin{array}{c}-0.25^{* * *} \\
(0.03)\end{array}$ & $\begin{array}{l}0.20^{* * *} \\
(0.02)\end{array}$ & $\begin{array}{l}0.49^{* * * *} \\
(0.03)\end{array}$ & $\begin{array}{l}0.32^{* * *} \\
(0.04)\end{array}$ & $\begin{array}{c}0.11^{* * *} \\
(0.01)\end{array}$ \\
\hline$\Delta R D * \phi$ & $\begin{array}{c}0.06 \\
(0.05)\end{array}$ & $\begin{array}{l}0.70^{* * *} \\
(0.10)\end{array}$ & $\begin{array}{c}-0.64^{* * *} \\
(0.07)\end{array}$ & $\begin{array}{c}-1.33^{* * *} \\
(0.21)\end{array}$ & $\begin{array}{c}-0.94^{* * *} \\
(0.16)\end{array}$ & $\begin{array}{c}-0.33^{* * *} \\
(0.04)\end{array}$ \\
\hline Obs. & 212 & 212 & 212 & 212 & 212 & 212 \\
\hline
\end{tabular}

Notes to table 17: [1] All dependent variables are log changes in the number of workers engaged in paid occupation (employee) or as self-employed in the TTWA from 2001 to 2011. [2] Calculations include only individuals from 16 to 64 . Columns 1 and 2 are total number of employee and selfemployed while column 3 is the ratio between 1 and 2. Columns 4, 5 and 6 compute the ratio in 3 by age group as labelled in the column headers. [3] All regressions include country dummies and errors are clustered at country level. [4] Coefficients that are statistically significant are denoted by the following system: ${ }^{*} 10 \%,{ }^{* * 5 \%}$ and ${ }^{* * *} 1 \%$ 
Table 18: The effect of R\&D on paid and self-employment, by age cohorts

\begin{tabular}{|c|c|c|c|c|c|c|}
\hline & \multicolumn{2}{|c|}{$16-24$} & \multicolumn{2}{|c|}{$25-34$} & \multicolumn{2}{|c|}{$35-64$} \\
\hline & $\begin{array}{c}\operatorname{Ln}\left(E_{k}\right) \\
(1)\end{array}$ & $\begin{array}{c}\frac{E_{k}}{E} \\
(2)\end{array}$ & $\begin{array}{l}E_{k} \\
\text { (3) }\end{array}$ & $\begin{array}{c}\frac{E_{k}}{E} \\
(4)\end{array}$ & $\begin{array}{l}E_{k} \\
(5)\end{array}$ & $\begin{array}{c}\frac{E_{k}}{E} \\
(6)\end{array}$ \\
\hline \multicolumn{7}{|c|}{ a. Employee } \\
\hline \multicolumn{7}{|c|}{ Baseline } \\
\hline \multirow[t]{2}{*}{$\Delta R D$} & $0.07^{* * *}$ & $0.02^{* * *}$ & $-0.19^{* * * *}$ & $-0.03^{* * *}$ & $-0.02^{*}$ & $0.01^{* * *}$ \\
\hline & $(0.02)$ & $(0.00)$ & $(0.01)$ & $(0.00)$ & $(0.01)$ & $(0.00)$ \\
\hline \multirow[t]{2}{*}{ Obs. } & 212 & 212 & 212 & 212 & 212 & 212 \\
\hline & \multicolumn{4}{|c|}{ By TTWA routinisation } & & \\
\hline \multirow[t]{2}{*}{$\triangle R D$} & $0.18^{* * *}$ & $0.03^{* * *}$ & $-0.22^{* * *}$ & $-0.03^{* * *}$ & $-0.05^{* *}$ & 0.00 \\
\hline & $(0.04)$ & $(0.01)$ & $(0.03)$ & $(0.00)$ & $(0.02)$ & $(0.01)$ \\
\hline \multirow[t]{2}{*}{$\Delta R D * \phi$} & $-0.91^{* * *}$ & $-0.14^{* * *}$ & $0.25^{*}$ & $0.04^{* *}$ & $0.23^{* * *}$ & $0.10^{* * *}$ \\
\hline & $(0.19)$ & $(0.03)$ & $(0.13)$ & $(0.01)$ & $(0.04)$ & $(0.02)$ \\
\hline Obs. & 212 & 212 & 212 & 212 & 212 & 212 \\
\hline \multicolumn{7}{|c|}{ b. Self-Employed } \\
\hline & & Base & & & & \\
\hline \multirow[t]{2}{*}{$\Delta R D$} & $-0.25^{* * *}$ & $-0.00^{* * *}$ & $-0.39^{* * *}$ & $-0.05^{* * *}$ & $-0.09^{* * *}$ & $0.05^{* * *}$ \\
\hline & $(0.03)$ & $(0.00)$ & $(0.03)$ & $(0.00)$ & $(0.01)$ & $(0.00)$ \\
\hline \multirow[t]{2}{*}{ Obs. } & 212 & 212 & 212 & 212 & 212 & 212 \\
\hline & \multicolumn{4}{|c|}{ By TTWA routinisation } & & \\
\hline \multirow[t]{2}{*}{$\Delta R D$} & $-0.30^{* * *}$ & $-0.00^{* * * *}$ & $-0.54^{* * *}$ & $-0.06^{* * *}$ & $-0.16^{* * *}$ & $0.06^{* * *}$ \\
\hline & $(0.02)$ & $(0.00)$ & $(0.06)$ & $(0.01)$ & $(0.03)$ & $(0.00)$ \\
\hline \multirow[t]{2}{*}{$\Delta R D * \phi$} & $0.42^{* * *}$ & 0.00 & $1.19^{* * *}$ & $0.10^{* * *}$ & $0.56^{* * *}$ & $-0.10^{* * *}$ \\
\hline & $(0.03)$ & $(0.00)$ & $(0.24)$ & $(0.02)$ & $(0.08)$ & $(0.02)$ \\
\hline Obs. & 212 & 212 & 212 & 212 & 212 & 212 \\
\hline
\end{tabular}

Notes to table 18: [1] All dependent variables are log changes in the TTWA from 2001 to 2011. Column 1 includes the number of workers who are employee or self employed, indexed by $k$, within the 16-24 age cohort, column 2 is the ratio of this category among all employed individuals within the 16-24 age cohort. Columns 3 to 6 replicate this structire for the other two remaining cohorts. [2] All regressions include country dummies and errors are clustered at country level. [3] Coefficients that are statistically significant are denoted by the following system: ${ }^{*} 10 \%,{ }^{* *} \%$ and ${ }^{* * *} 1 \%$ 


\section{Recent papers in the SPRU Working Paper Series:}

\section{March}

Industrial Policy for a European Industrial Renaissance. A Few Reflections. Maria Savona

\section{January}

Patent-based Estimation Procedure of Private R\&D: The Case of Climate Change and Mitigation Technologies in Europe. Francesco Pasimeni, Alessandro Fiorini and Aliki Georgakaki

Reorienting Finance Towards Energy Efficiency: The Case of UK Housing. Noam Bergman and Tim Foxon

Innovation for Inclusive Structural Change. A Framework and Research Agenda. Tommaso Ciarli, Maria Savona, Jodie Thorpe and Seife Ayele

System Transition and Structural Change Processes in the Energy Efficiency of Residential Sector: Evidence from EU Countries. Valeria Costantini, Francesco Crespi, Elena Paglialunga and Giorgia Sforna

Technological Innovation, Entrepreneurship and Productivity in Germany, 1871-2015. Wim Naudé and Paula Nagler

Innovation, Structural Change, and Inclusion. A Cross Country PVAR Analysis. Amrita Saha and Tommaso Ciarli

\section{November}

A New 'Cut' on Technological Innovation Aiming for Sustainability in a Globalized World. Adela Conchado and Pedro Linares

Resource Efficiency, Environmental Policy and Eco-Innovations for a Circular Economy: Evidence from EU Firms. Giulio Cainelli, Alessio D'Amato and Massimiliano Mazzanti

Exploring Perceptions of the Credibility of Policy Mixes: The Case of German Manufacturers of Renewable Power Generation Technologies. Karoline S. Rogge and Elisabeth Dütschke

\section{Suggested citation:}

Tommaso Ciarli, Alberto Marzucchi, Edgar Salgado and Maria Savona (2018). The Effect of R\&D Growth on Employment and Self-Employment in Local Labour Markets. SPRU Working Paper Series (SWPS), 2018-08: 1-38. ISSN 2057-6668. Available at: www.sussex.ac.uk/spru/swps2018-08

\section{SPRU - Science Policy Research Unit}

University of Sussex

Falmer, Brighton, BN1 9SL,United Kingdom

SWPS Website: www.sussex.ac.uk/spru/research/swps

SPRU Website: www.sussex.ac.uk/spru

SPRU Twitter: @SPRU 